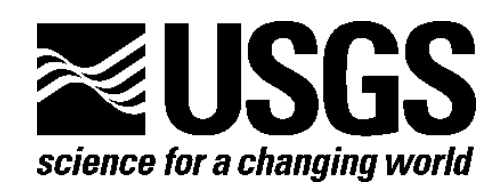

\title{
Gold Deposits of the Carolina Slate Belt, Southeastern United States: Age and Origin of the Major Gold Producers
}

By Nora K. Foley and Robert A. Ayuso

Open-File Report 2012-1179

U.S. Department of the Interior U.S. Geological Survey 


\section{U.S. Department of the Interior \\ KEN SALAZAR, Secretary}

\section{U.S. Geological Survey \\ Marcia K. McNutt, Director}

U.S. Geological Survey, Reston, Virginia: 2012

For more information on the USGS-the Federal source for science about the Earth, its natural and living resources, natural hazards, and the environment-visit http://www.usgs.gov or call 1-888-ASK-USGS

For an overview of USGS information products, including maps, imagery, and publications, visit http://www.usgs.gov/pubprod

To order this and other USGS information products, visit http://store.usgs.gov

Suggested citation:

Foley, N.K., and Ayuso, R.A., 2012, Gold deposits of the Carolina Slate Belt, southeastern United States-Age and origin of the major gold producers: U.S. Geological Survey Open-File Report 2012-1179, 26 p.

Any use of trade, product, or firm names is for descriptive purposes only and does not imply endorsement by the U.S. Government.

Although this report is in the public domain, permission must be secured from the individual copyright owners to reproduce any copyrighted material contained within this report. 


\section{Contents}

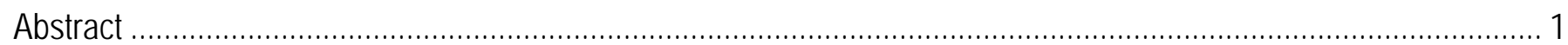

Introduction

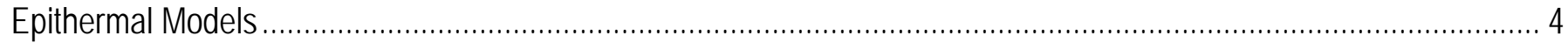

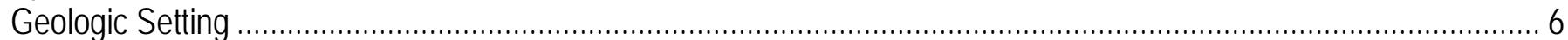

Significance of Neoproterozoic Gold Deposits..................................................................................... 9

Rocks of Persimmon Fork, Uwharrie, and Tillery Formations ........................................................................ 10

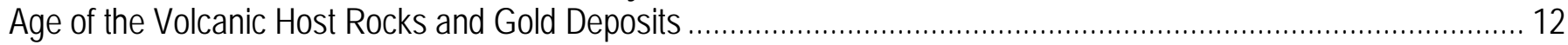

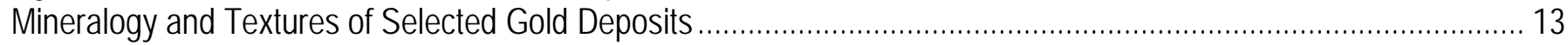

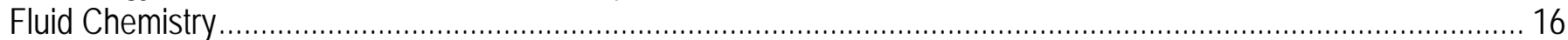

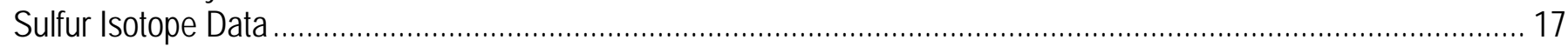

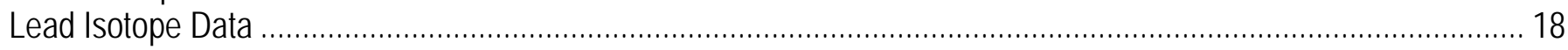

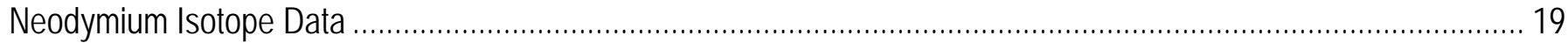

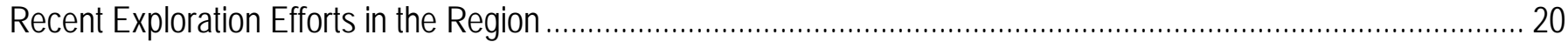

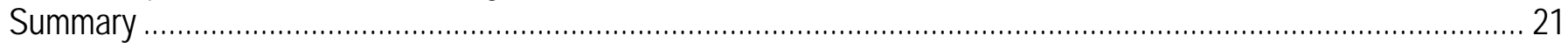

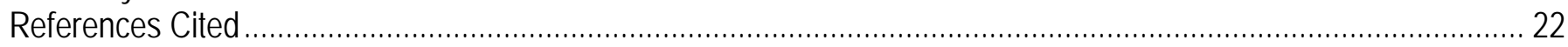

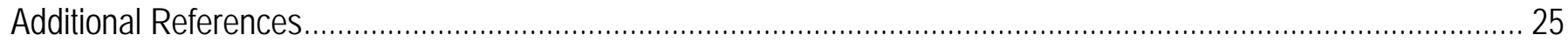

\section{Figures}

1. Historic open pit of the Haile Gold Mine, South Carolina .................................................................... 2

2. Gold grades and tonnages for deposit types similar to the Haile and Ridgeway deposits .............................. 3

3. Geologic environments for volcanic-related gold deposits ..................................................................... 4

4. The regional distribution of rocks in the Carolina and Avalonian tectonic zones............................................ 6

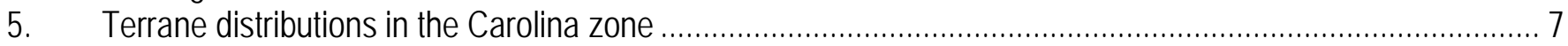

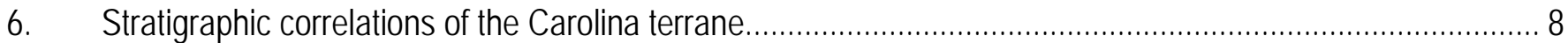

7. Secular variations in gold resources, Carolina Slate Belt ........................................................................ 9

8. Photographs of rocks of the Persimmon Fork and Uwharrie Formations: (1-3) silicified metatuff and tuffaceous siltstone typical of rocks near the gold deposits, (4) tectonic breccia at Haile, (5-6) pyrite cemented breccias and silicified and mineralized hydrothermal stockwork in subvolcanic porphyry, (7-8) phyllite and mudstone of the Tillery Formation

9. Plots of tantalum-ytterbium (Ta-Yb) for the Persimmon Fork Formation and regional equivalents .................. 11

10. Age dating of host rocks and gold deposits of the Carolina Slate Belt..................................................... 12

11. Mineralogies and textures of three types of selected gold deposits in the Carolina Slate Belt....................... 13

12. Evidence in ore textures for the presence of early epithermal gold mineralization ....................................... 14

13. Evidence in volcanic rock textures for the presence of early epithermal gold mineralization ......................... 15

14. Fluid inclusion data for the major gold deposits compared to classic datasets for high- and low-sulfidation (HS, LS) epithermal deposits and gold-rich volcanogenic massive sulfide (VMS)

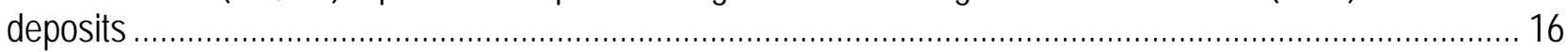

15. Sulfur isotope data for ore deposits of the Carolina Slate Belt............................................................ 17

16. Lead isotope compositions for the gold deposit of the Carolina Slate Belt ................................................ 18

17. Neodymium isotope data for host rocks and gold deposits of the Carolina Slate Belt .................................. 19

18. Locations of recent exploration and drilling by companies referred to in the text........................................... 20 


\section{Tables}

1. The Haile Gold Mine reserve and resource estimates .........................................................................

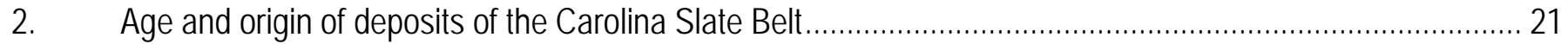

\section{Conversion Factors, Abbreviations and Acronyms, and Symbols}

Inch/Pound to SI

\begin{tabular}{|c|c|c|}
\hline Multiply & By & To obtain \\
\hline \multicolumn{3}{|c|}{ Volume } \\
\hline ounce, fluid & 0.02957 & liter \\
\hline \multicolumn{3}{|l|}{ SI to Inch/Pound } \\
\hline Multiply & By & To obtain \\
\hline \multicolumn{3}{|c|}{ Length } \\
\hline kilometer (km) & 0.6214 & mile (mi) \\
\hline \multicolumn{3}{|c|}{ Mass } \\
\hline gram (g) & 0.03527 & ounce, avoirdupois (oz) \\
\hline megagram (Mg) & 1.102 & ton, short $(2,000 \mathrm{lb})$ \\
\hline megagram (Mg) & 0.9842 & ton, long (2,240 lb) \\
\hline
\end{tabular}

Temperature in degrees Celsius $\left({ }^{\circ} \mathrm{C}\right)$ may be converted to degrees Fahrenheit $\left({ }^{\circ} \mathrm{F}\right)$ as follows:

${ }^{\circ} \mathrm{F}=\left(1.8 x^{\circ} \mathrm{C}\right)+32$

\section{Abbreviations and Acronyms}

$\begin{array}{llllll}\mathrm{AFM} & \begin{array}{l}\text { an AFM diagram is a three- } \\ \text { component triangular graph }\end{array} & \mathrm{K} & \text { potassium } & \mathrm{ppm} & \text { parts per million } \\ \mathrm{Ag} & \text { silver } & \mathrm{kg} & \text { kilogram } & \mathrm{Re} & \text { rhenium } \\ \mathrm{As} & \text { arsenic } & \mathrm{Ma} & \text { million years } & \mathrm{REE} & \text { rare earth element } \\ \mathrm{Au} & \text { gold } & \mathrm{Mgo} & \text { magnesium oxide } & \mathrm{Ta} & \text { tantalum } \\ \mathrm{CO}_{2} & \text { carbon dioxide } & \mathrm{Mo} & \text { molybdenum } & \mathrm{Te} & \text { tellurium } \\ \mathrm{CSB} & \text { Carolina Slate Belt } & \mathrm{Moz} & \text { million ounces } & \mathrm{U} & \text { uranium } \\ \mathrm{Cu} & \text { copper } & \mathrm{NaCl} & \text { sodium chloride } & \mathrm{VAG} & \text { volcanic arc granites } \\ \mathrm{Fe} & \text { iron } & \mathrm{Nd} & \text { neodymium } & \mathrm{VMS} & \text { volcanogenic massive sulfide } \\ \mathrm{Fm} & \text { formation } & \mathrm{Os} & \text { osmium } & \mathrm{Yb} & \text { ytterbium } \\ \mathrm{Ga} & \text { giga annum } & \mathrm{Pb} & \text { lead } & \mathrm{Zn} & \text { zinc }\end{array}$

\section{Symbols}

approximately

$<\quad$ less than

$\% \quad$ percent 


\title{
Gold Deposits of the Carolina Slate Belt, Southeastern United States: Age and Origin of the Major Gold Producers
}

\author{
By Nora K. Foley and Robert A. Ayuso
}

Invited paper for a Special Session on Mining in the United States at the 2012 Prospectors \& Developers Association of Canada International Convention, Trade Show \& Investors Exchange, Toronto, Canada, March 7, 2012. Numbered figures in this report were originally prepared as slides.

\begin{abstract}
Gold- and iron sulfide-bearing deposits of the southeastern United States have distinctive mineralogical and geochemical features that provide a basis for constructing models of ore genesis for exploration and assessment of gold resources. The largest (historic) deposits, in approximate million ounces of gold (Moz Au), include those in the Haile ( 4.2 Moz Au), Ridgeway ( 1.5 Moz Au), Brewer ( $\sim 25 \mathrm{Moz} \mathrm{Au})$, and Barite Hill (0.6 Moz Au) mines. Host rocks are Late Proterozoic to early Paleozoic ( $\sim 53$ million years old) metaigneous and metasedimentary rocks of the Carolina Slate Belt that share a geologic affinity with the classic Avalonian tectonic zone. The inferred syngenetic and epithermal-subvolcanic quartz-porphyry settings occur stratigraphically between sequences of metavolcanic rocks of the Persimmon Fork and Uwharrie Formations and overlying volcanic and epiclastic rocks of the Tillery and Richtex Formations (and regional equivalents). The Carolina Slate Belt is highly prospective for many types of gold ore hosted within quartz-sericite-pyrite altered volcanic rocks, juvenile metasedimentary rocks, and in associated shear zones. For example, sheared and deformed auriferous volcanogenic massive sulfide deposits at Barite Hill, South Carolina, and in the Gold Hill trend, North Carolina, are hosted primarily by laminated mudstone and felsic volcanic to volcaniclastic rocks. The high-sulfidation epithermal style of gold mineralization at Brewer and lowsulfidation gold ores of the Champion pit at Haile occur in breccias associated with subvolcanic quartz porphyry and within crystal-rich tuffs, ash flows, and subvolcanic rhyolite. The Ridgeway and Haile deposits are primarily epithermal replacements and feeder zones within (now) metamorphosed crystalrich tuffs, volcaniclastic sediments, and siltstones originally deposited in a marine volcanic-arc basinal setting. Recent discoveries in the region include (1) extensions of known deposits, such as at Haile where drilling has identified an extensive gold-rich feeder system; and (2) newly discovered prospects like the porphyry-style gold-copper-molybdenum occurrence reported at Deep River, N.C. Gold ores at Ridgeway and Haile represent the low-sulfidation, disseminated, shallow subaqueous tuffaceous equivalents of intrusion-related high-sulfidation ores such as those at Brewer. Haile also has mineralogical features that support a stockwork disseminated model of pyrite-gold-sericite mineralization in which a significant amount of ore was deposited in sediments at or near the surface. The potential is high for gold-rich ore at depth in the funnel-shaped feeder zones that likely underlie such surface variants of high sulfidation-low sulfidation epithermal systems and for new discoveries of similar deposits in areas undercover. Exploration strategies for large-scale gold-mineralizing systems
\end{abstract}


applied to rocks of the Carolina Slate Belt, and by extension, the Carolinian-Avalonian tectonic zone of North America, benefit from applying subvolcanic and basinal epithermal models for gold mineralization.

\section{Introduction}

Today I am going to talk about the age and origin of Neoproterozoic gold deposits that occur within the Carolina Slate Belt (Slate Belt) in the southeastern United States. This presentation includes an up-to-date summary of the results of studies conducted in the region by a U.S. Geological Survey group led by Robert A. Ayuso. The group included Sandra H.B. Clark, Nora K. Foley, Terry L. Klein, Terry W. Offield, and Robert R. Seal.

\section{Haile Gold Mine, South Carolina}

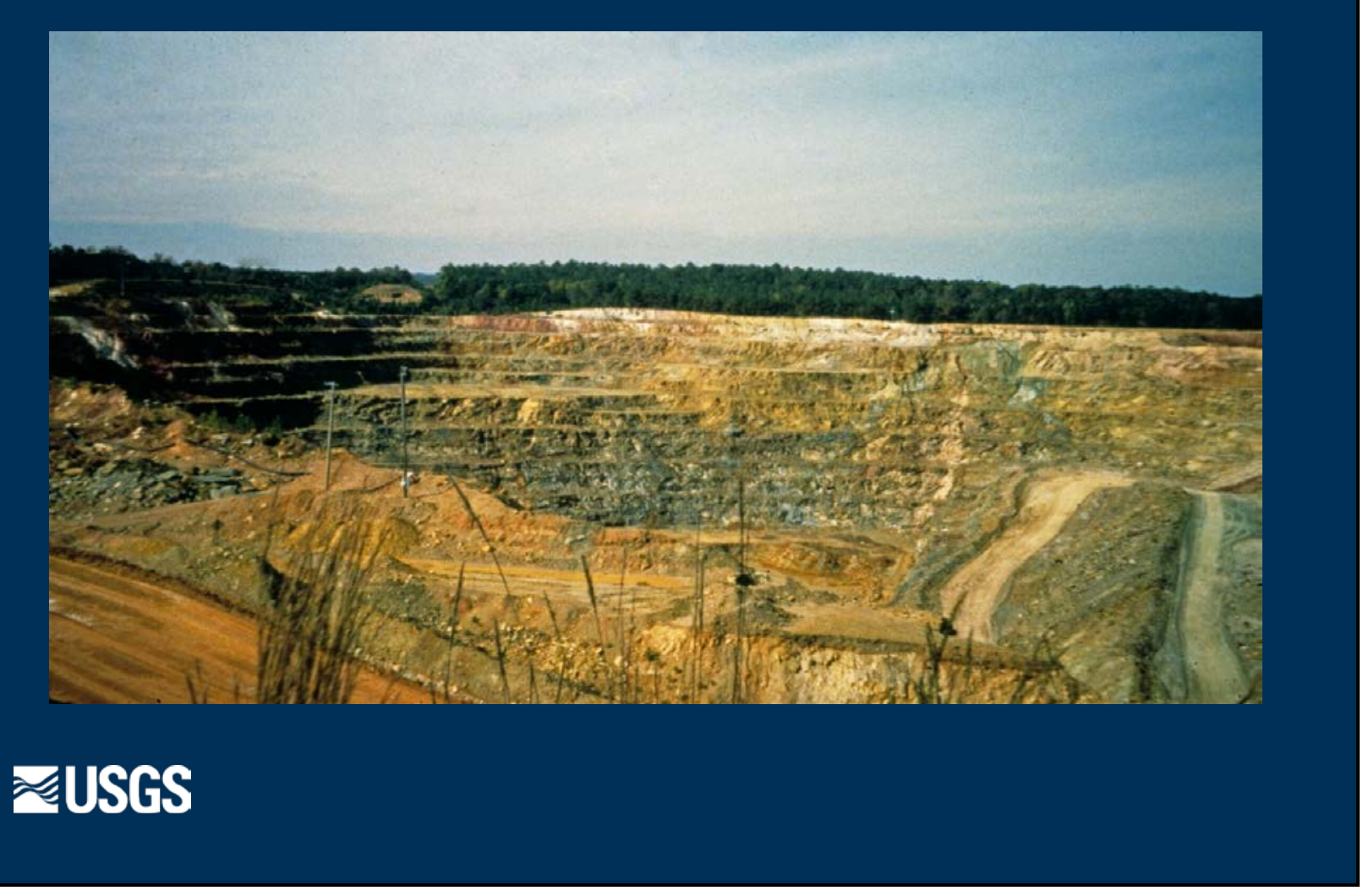

Figure 1. Historic open pit of the Haile Gold Mine, South Carolina.

The photograph shown in figure 1 was taken about 1998, and it shows the open pit of the Haile deposit of Lancaster County, South Carolina, which produced approximately 50 metric tons of gold. New and more recent drilling by Romarco Minerals Inc. has delineated an additional 115 metric tons of gold $(\mathrm{Au})$, bringing the estimate of the amount of contained gold in this one Slate Belt gold deposit to well over 160 metric tons ( $\sim 5.6$ million ounces of gold, table 1$)$. This morning I am going to summarize 
some of the major ideas with respect to the age and evolution of the rocks that host the largest of the gold deposits and the range of mineralization styles and deposit models that are now being applied to exploration and assessment activities related to the gold resources in the region.

Table 1. The Haile Gold Mine reserve and resource estimates.

[Accessed March 13, 2012, at http://www.romarco.com/Our-Projects/Haile/Haile-Overview/default.aspx]

\begin{tabular}{lccr}
\hline \multicolumn{1}{c}{ Resource } & $\begin{array}{c}\text { Tonnage } \\
\text { (million tonnes) }\end{array}$ & $\begin{array}{c}\text { Grade } \\
\text { (grams/tonne) }\end{array}$ & $\begin{array}{c}\text { Total gold } \\
\text { (ounces) }\end{array}$ \\
\hline Measured and Indicated & 71.2 & 1.77 & $4,000,000$ \\
Inferred & 20.1 & 1.24 & 800,000 \\
Proven and Probable & 30.5 & 2.06 & $2,000,000$ \\
\hline
\end{tabular}

\section{Gold grades and tonnages}

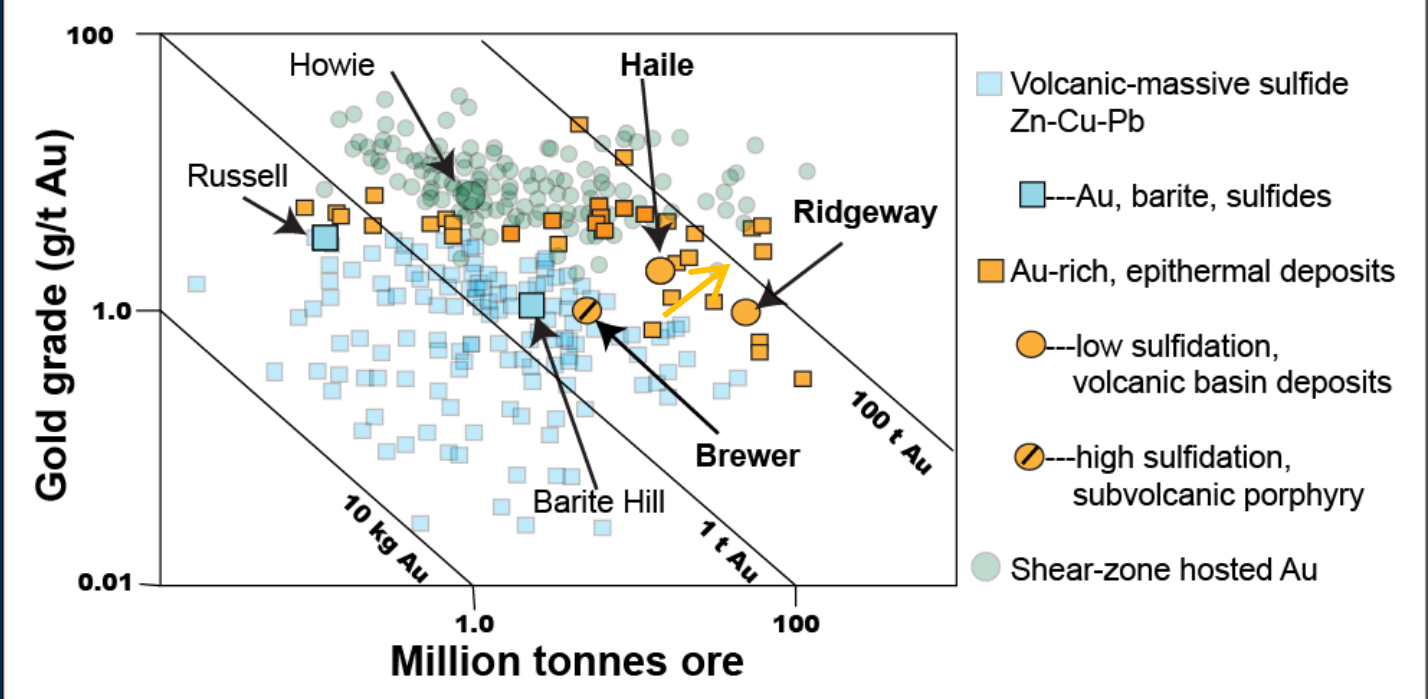

- What distinguishes Haile and Ridgeway?

- How much Au remains in the Carolinas? ¿USGS

Figure 2. Gold grades and tonnages for deposit types similar to the Haile and Ridgeway deposits.

The Carolina Slate Belt is part of a package of rocks that extends from Alabama to Virginia and contains over 1,500 documented occurrences of gold. On figure 2, which shows grade versus tonnage, we have plotted produced gold for a number of Carolina Slate Belt gold deposits in comparison with published data sets for VMS (volcanogenic massive sulfide) deposits in blue squares (Galley and others, 
2007), shear-zone gold deposits in green circles (Mutschler and Mooney, 1993), and some epithermaltype deposits in orange (Heald and others, 1987). With gold projected by some commodity analysts to exceed \$1,800/ounce by the end of 2012, and with a focus on job and economic challenges in the United States, some questions worth revisiting examine what distinguishes the larger deposits at Haile and Ridgeway from other gold occurrences in the region and what the potential is for additional discoveries of large gold resources in the Slate Belt.

Historically, the Slate Belt deposits have produced gold ranging from about 1 metric ton from small operations to well over 50 metric tons. The wide range in the size of the Slate Belt gold deposits is due, in part, to the fact that historic producers include small Au-VMS deposits like Barite Hill in southern South Carolina (Clark and others, 2000; Seal and others, 2001) and shear-zone-hosted orogenic-style deposits like those at the Howie mine, Union County, North Carolina (Foley, unpublished data, 2012). In contrast, the larger gold deposits - such as those at Haile and Ridgeway in central South Carolina-are generally now thought to belong to the epithermal class (Foley and others, 2007). For many years their origin was controversial because of their age and complex history of deformation and metamorphism. The data presented here support an epithermal origin for the largest deposits.

\section{Epithermal Models}

\section{Gold in epithermal deposits}

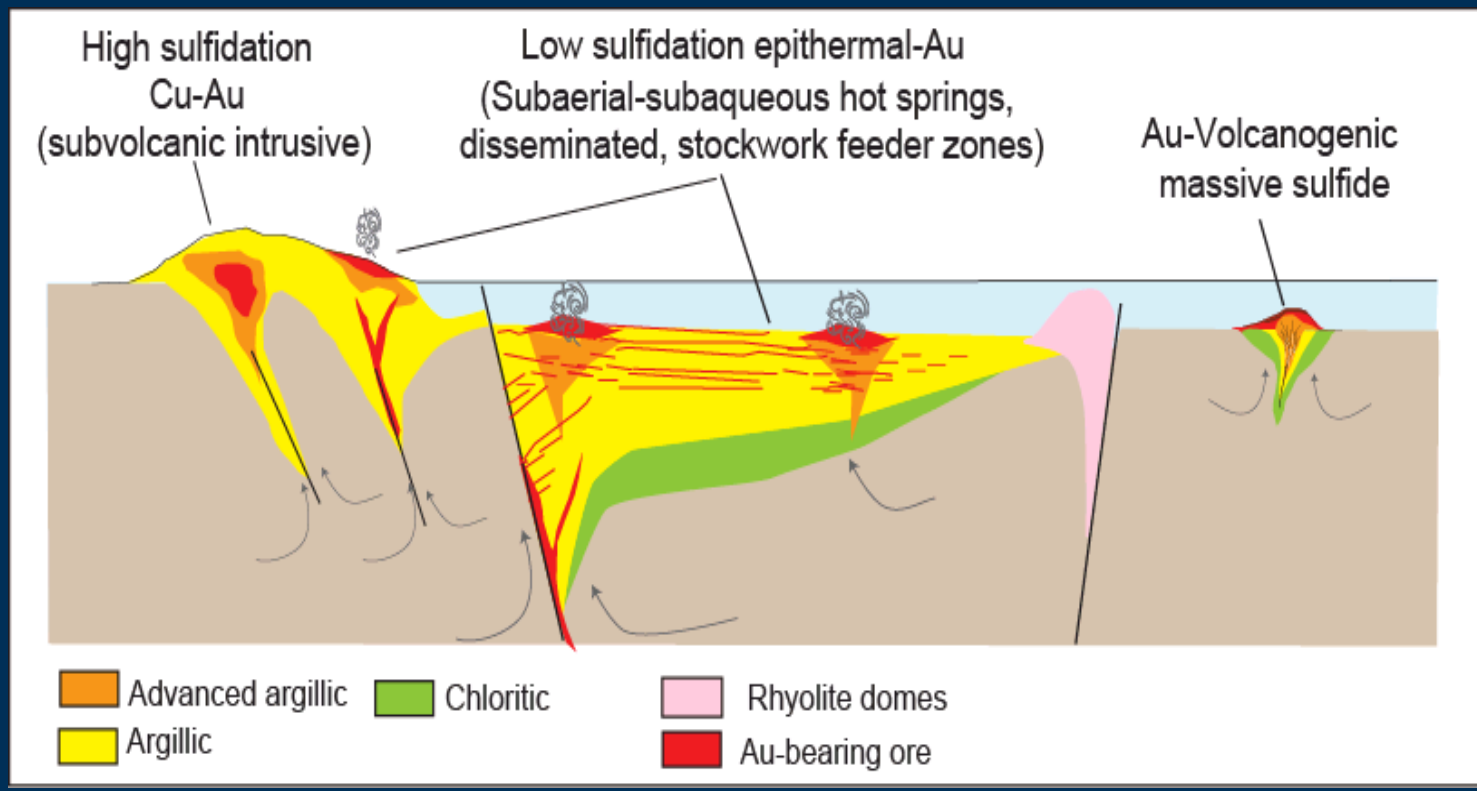

\section{¿USGS}

Figure 3. Geologic environments for volcanic-related gold deposits. 
Figure 3 shows a continuum of geologic environments for volcanic-related gold deposits formed in submarine-to-subaerial and volcanic-to-plutonic settings. These include, from left to right, shallowly emplaced high-sulfidation copper-gold epithermal systems, such as are found at the Brewer mine in central South Carolina, which produced approximately 5 metric tons of gold; low-sulfidation epithermal systems, such as are found at Ridgeway and Haile, which both produced in the range of 50 metric tons of gold; and also gold-rich volcanogenic massive sulfide systems, such as the auriferous base-metalsulfide-rich ores at the Barite Hill deposit, which produced about 2 metric tons of gold. Some noteworthy studies relating to the genesis of gold deposits of the Carolina Slate belt include these: Worthington and Kiff (1970), Feiss and others (1993), Gillon and others (1995,1998), Maddry and Kilbey (1995), Zwaschka and Scheetz (1995), Clark and others (2000), Seal and others (2001), Foley and others (2001), Ayuso and others (2005), Foley and others (2007), and Klein and others (2007).

Most modern thinking on epithermal deposits, especially those having a high sulfidation signature, considers that deep porphyry copper \pm gold systems constitute the magmatic roots of shallow epithermal gold systems (for example, Sillitoe and Hedenquist, 2003). With respect to the Slate Belt, a critical question is how closely are these epithermal deposits linked to deep porphyry systems: Do these deposits, in fact, have porphyry roots? Or has, for example, extensional tectonism in the form of largescale crustal faulting and uplift (as described by Tosdal and others, 2009) resulted in near-surface magmatic-hydrothermal gold systems without roots? 


\section{Geologic Setting}

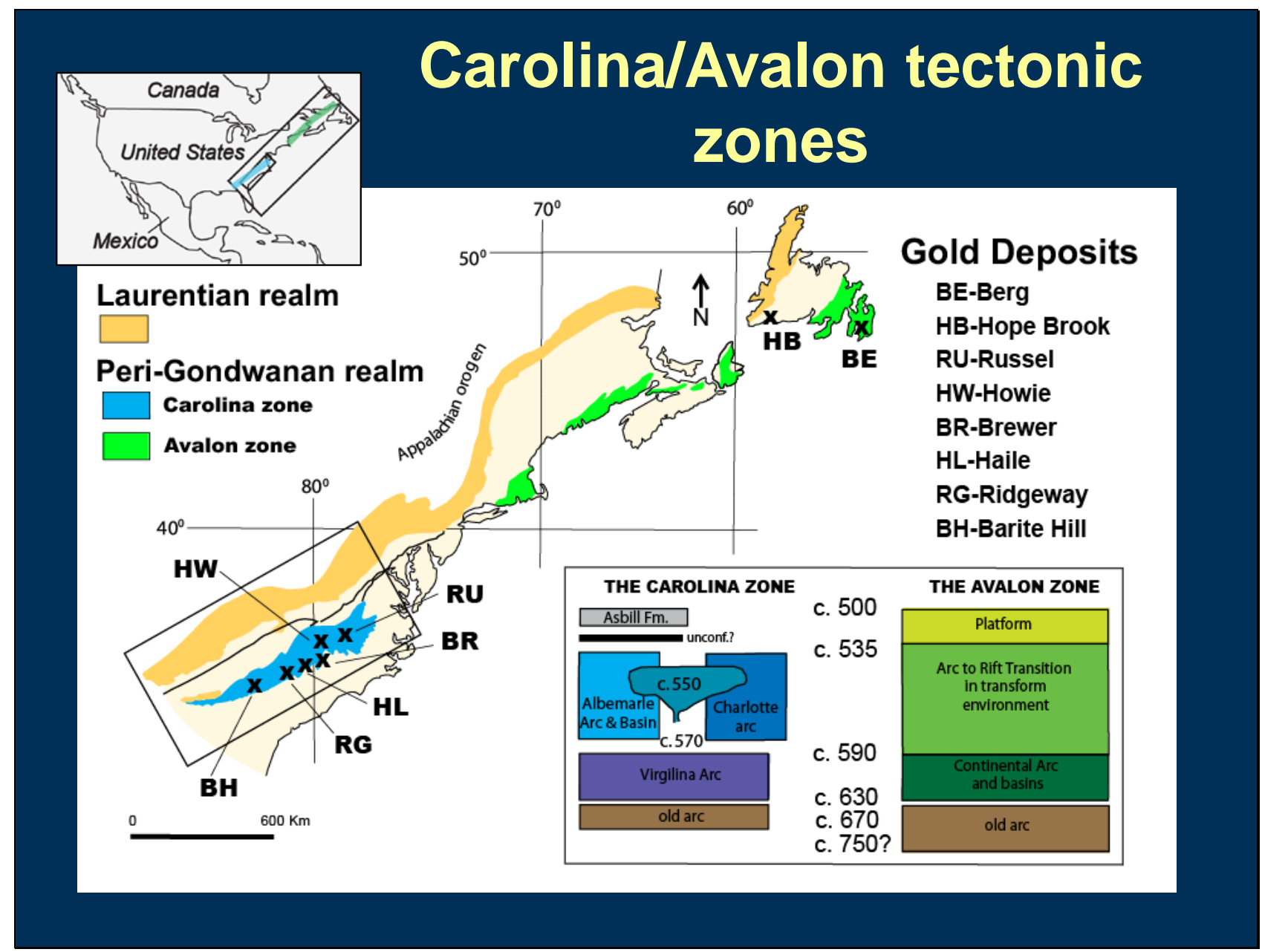

Figure 4. The regional distribution of rocks in the Carolina and Avalonian tectonic zones. Modified from Hibbard and others (2002) and Hibbard and others (2005).

Taking a step back, the map in figure 4 shows the regional distribution of rocks in the Carolina and Avalonian tectonic zones; the Carolina zone, shown in blue, hosts the gold deposits of the Slate Belt. The Carolina terrane has long been considered by many to be a southern extension of the Avalon terrane (Shervais and others, 1996; Dennis and Wright, 1997; Dennis and others, 2004; Hibbard and others, 2002, 2005; Murphy and others, 1999), which also contains large epithermal deposits—for example, the Hope Brook deposit, Newfoundland, Canada (Dubè and others, 1998), which reportedly contains more than 45 metric tons of gold. Others now consider the Carolina terrane as a separate, independent crustal block that records a much longer tectono-thermal history with arc magmatism extending well into the Cambrian period (Hibbard and others, 2007, 2010; Pollock and Hibbard, 2009; Pollock and others, 2010). These studies establish that the Carolina zone is a remnant of a volcanic arc and that the major gold deposits likely formed in an arc-rift to back-arc basin setting on the margin of west Gondwana. The Carolina terrane was accreted to the eastern Laurentian margin probably in the Middle to Late Ordovician age (Hibbard and others, 2003). 


\section{Terrane distributions in the Carolina}

\section{Zone}

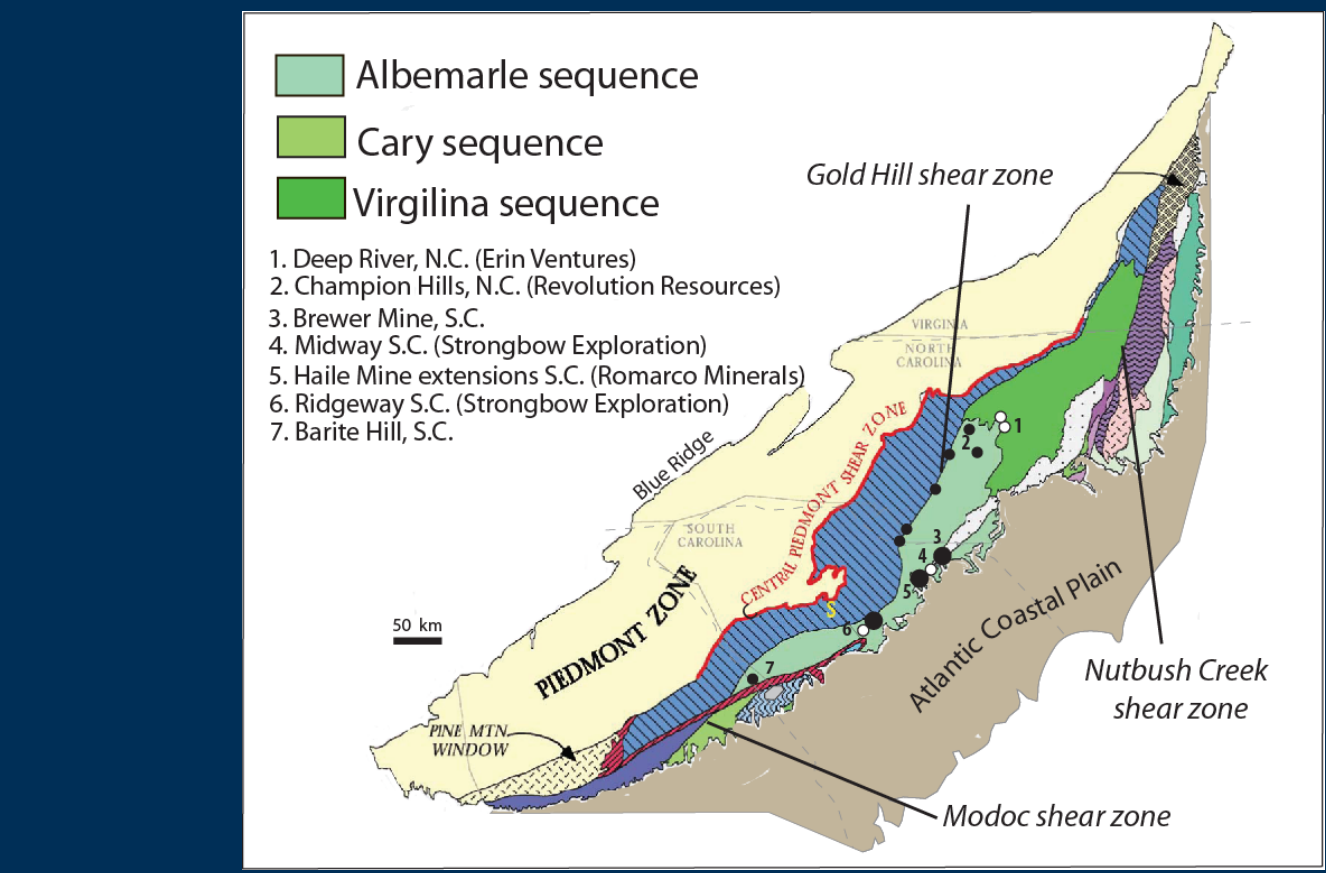

\section{‡USGS}

Figure 5. Terrane distributions in the Carolina zone. Modified from Hibbard and others (2002) and Hibbard and others (2005).

The three rock sequences that make up the Carolina zone (Hibbard and others, 2002, 2005) are shown on figure 5 in shades of green. The sequences consist mainly of Late Proterozoic to Cambrian metavolcanic rocks and associated epizonal plutons. The oldest is the Virgilina sequence, which is found mostly in North Carolina; the middle Cary sequence is restricted to a sliver of Georgia. The Albemarle sequence, which extends from Georgia to North Carolina, is the youngest, and it contains the units that host most of the known gold deposits and most of the new discoveries. These include the Champion Hills trend, North Carolina (location 2 on fig. 5); the Brewer mine, South Carolina (3); the Midway target, South Carolina (4); the Haile deposits and extension, South Carolina (5); the Ridgeway deposits, South Carolina (6); and the Barite Hill deposit, southern South Carolina (7). An interesting exception is the Deep River prospect, North Carolina (1), which is sited in rocks of the older Virgilina sequence but is apparently much younger in age (Rapprecht and others, 2010).

The sequences of the Carolina zone are bounded by shear zones of the Late Paleozoic age. These are the Modoc Shear zone to the southwest, the Nutbush Creek shear zone to the northeast, and the Gold Hill fault zone (Hibbard and others, 2003), which forms the contact of the Carolina Slate Belt with the Charlotte zone to the west. The Gold Hill fault zone contains numerous small shear-zone-hosted orogenic-style gold deposits (in the range of less than 5 metric tons). 
One last point to make is that a large extent of the eastern margin of the Albemarle sequence, in particular, is covered by onlapping sediments of the Atlantic Coastal Plain. These sediments run right up against the gold deposits in the vicinity of Haile and Brewer.

\section{Carolina Terrane stratigraphic correlations}

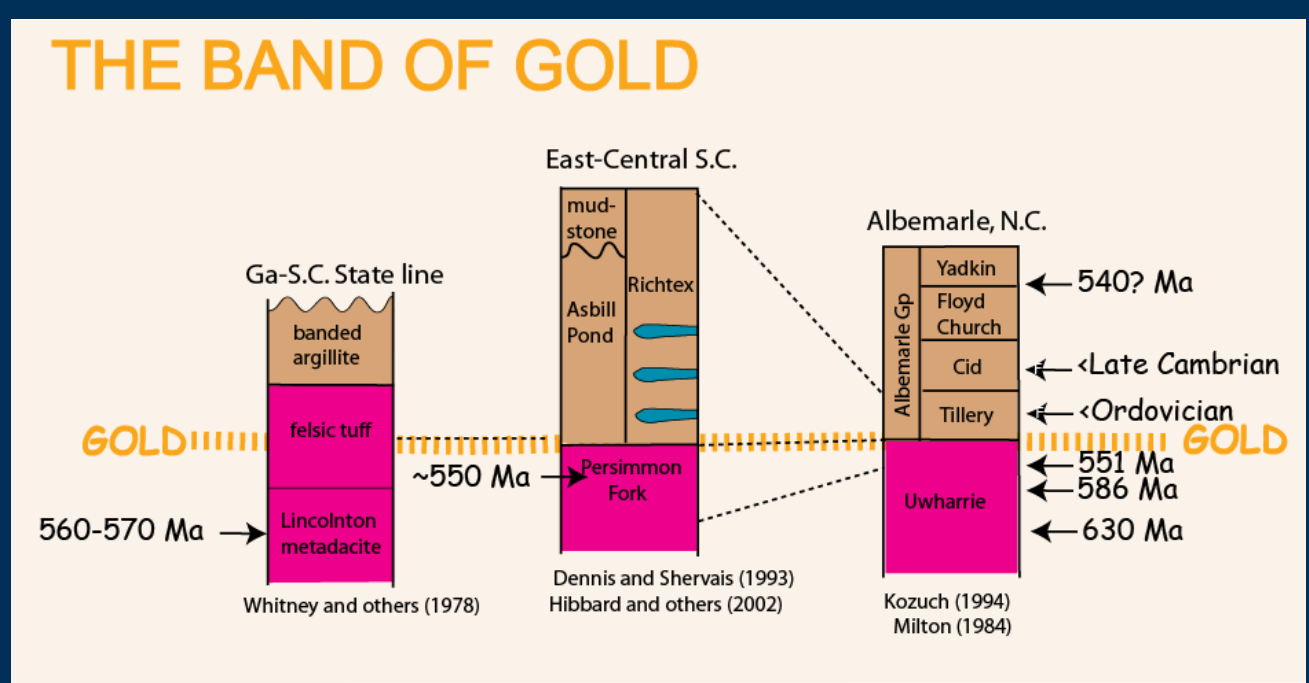

\section{ఇUSGS}

Figure 6. Stratigraphic correlations of the Carolina terrane.

Figure 6 shows stratigraphic correlations of the Carolina terrane from south to north and some of the available age dates. The main volcanic host for much of the gold mineralization is the Persimmon Fork Formation as defined in east-central South Carolina, which is correlative with the Uwharrie formation in North Carolina, and felsic metatuff near the Georgia-South Carolina state line. The known deposits are generally all located at or near the upper contact of the Persimmon Fork and Uwharrie Formations with overlying mudstones, siltstones, and mafic volcanic rocks of the Tillery and Richtex Formations. The Tillery and Richtex Formations and regional equivalents are generally undated but are thought to be older than Ordovician. Thus, the gold mineralization is bracketed by regional geology to the late Neopropertozoic. 


\section{Significance of Neoproterozoic Gold Deposits}

\section{Secular variation in Au resources}

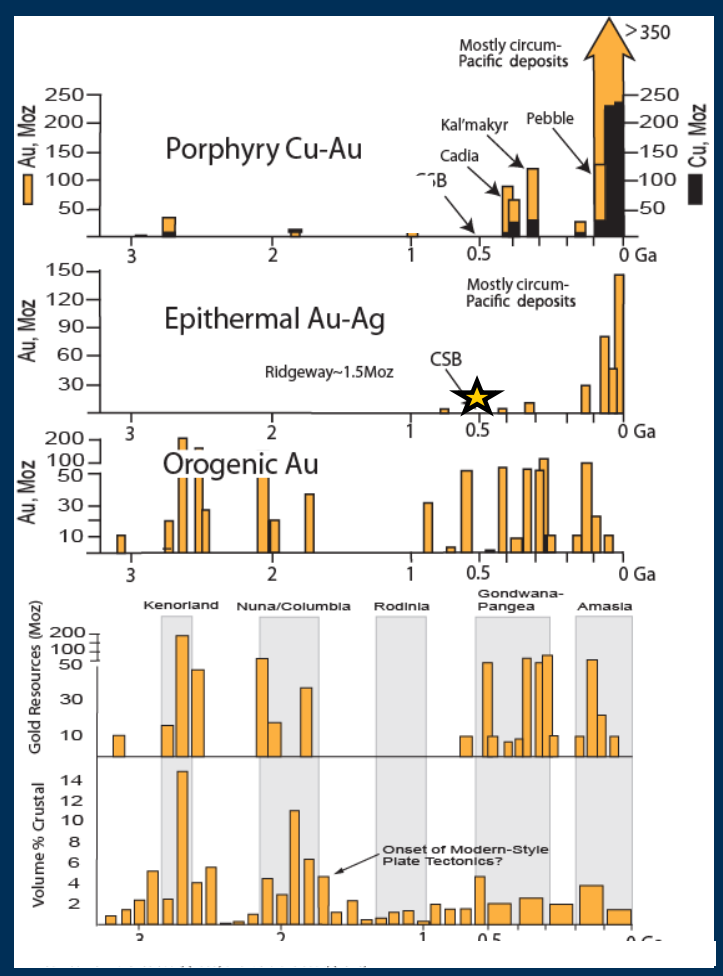

- Carolina terrane, CSB

- locally preserved shallow-

level remnant of

Neoproterozoic 'Gondwana'

- Contains some the oldest

known epithermal-Au

-Distinctive character

- Au-Cu-Ag-Mo-Pb-As-Te, REE signatures

- Fe-oxide /sulfide breccias, layers, mineralogy

- hydrothermal alteration assemblages and styles

Figure 7. Secular variations in gold resources, Carolina Slate Belt (Groves and others, 2005; Goldfarb and others, 2010).

Figure 7 shows a figure from the literature describing secular variations in gold resources for three types of gold deposits: porphyry $\mathrm{Cu}-\mathrm{Au}$, epithermal $\mathrm{Au}-\mathrm{Ag}$, and orogenic $\mathrm{Au}$. We'll focus on the data for epithermal deposits. I have added the age of the Slate Belt, shown with the gold star. The Carolina Slate Belt contains some of the oldest known epithermal deposits in the world. In general, these Neoproterozic epithermal gold deposits have important differences relative to, for example, the much younger, circum-Pacific type epithermal gold deposits and those occurring throughout the western United States (for example, John, 2001). These differences include a distinctive geochemical fingerprint, which includes $\mathrm{Au}, \mathrm{Cu}, \mathrm{Ag}, \mathrm{Mo}, \mathrm{Pb}, \mathrm{As}$, Te, and REE; the presence of Fe-sulfide and Feoxide breccias, layers, and stockwork veining; and also distinctive hydrothermal alteration styles. 


\section{Rocks of Persimmon Fork, Uwharrie, and Tillery Formations}

\section{Persimmon Fork, Uwharrie}
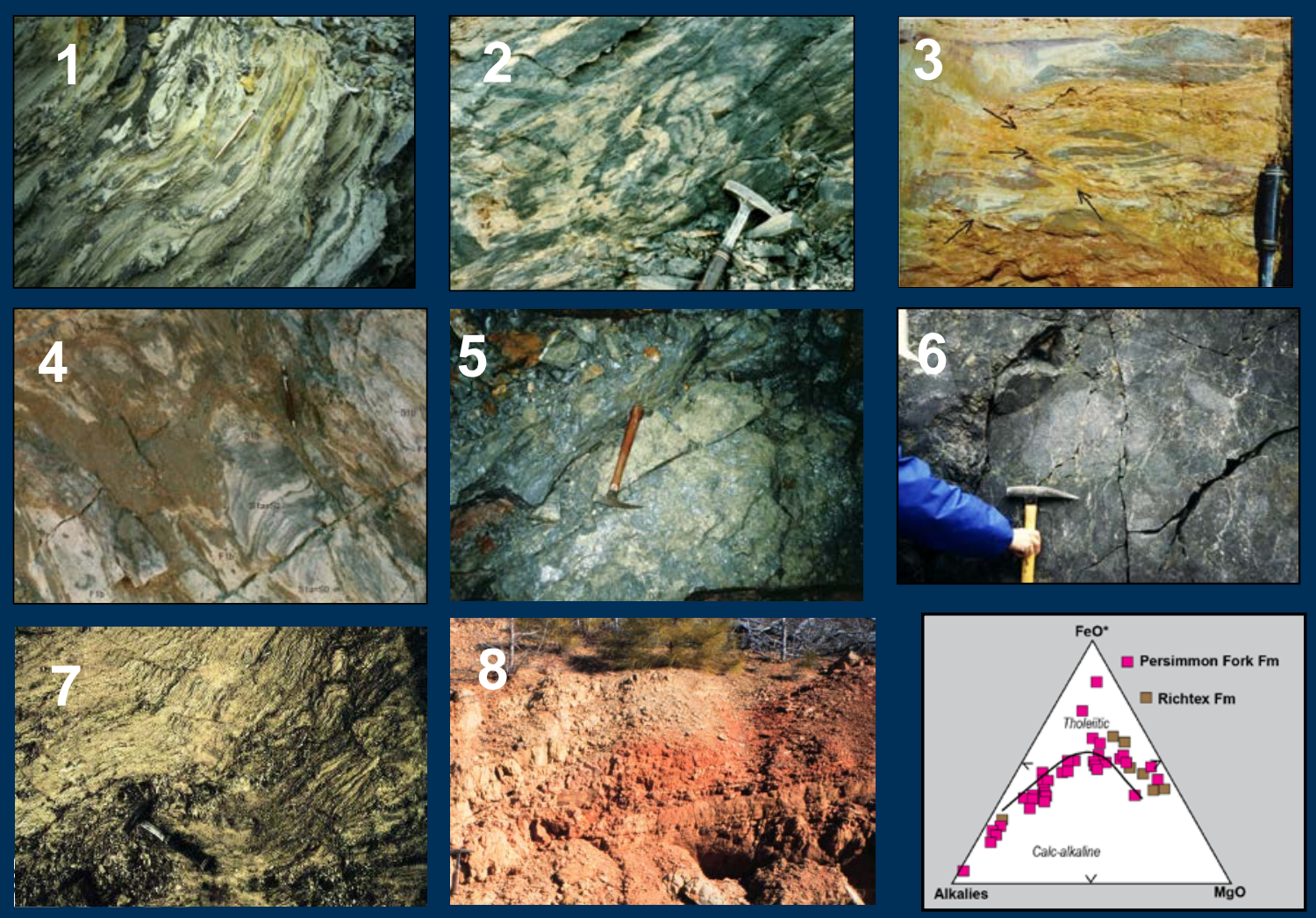

Figure 8. Photographs of rocks of the Persimmon Fork and Uwharrie Formations: (1-3) silicified metatuff and tuffaceous siltstone typical of rocks near the gold deposits, (4) tectonic breccia at Haile, (5-6) pyrite cemented breccias and silicified and mineralized hydrothermal stockwork in subvolcanic porphyry, (7-8) phyllite and mudstone of the Tillery Formation. An AFM diagram of Persimmon Form Formation shows a generally calc-alkaline trend.

The top row of figure 8 shows photographs of silicified metatuff and tuffaceous siltstone typical of the Persimmon Fork and Uwharrie Formations near the gold deposits at Haile, Ridgeway, and Brewer. The second row shows a tectonic breccia at Haile and pyrite cemented breccias and silicified and mineralized hydrothermal stockwork in subvolcanic porphyry at Brewer. The bottom row shows phyllite from the Gold Hill shear zone and a photograph of mudstone of the Tillery Formation. (All photographs by N.K. Foley, unpublished data, 2012.) As these photographs show, the types of rocks that comprise the ore hosts vary widely; the Persimmon Fork and Uwharrie Formations include felsic volcaniclastic rocks and mudstones, rhyolitic ashflows, crystal tuffs, and subvolcanic and plutonic intrusives. The overlying Richtex and Tillery Formations are composed of turbiditic metamudstones, metawacke, and interlayered mafic metavolcanics. All of the rocks are extensively deformed, metamorphosed, and saprolitically altered. 


\section{Trace element geochemistry}

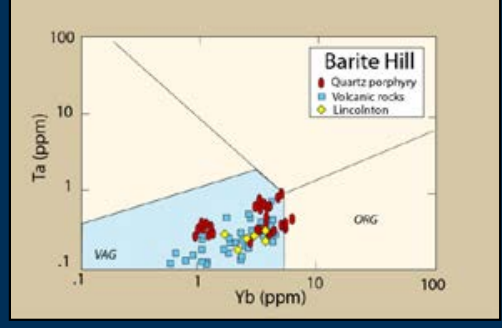

\section{- Host rocks}

- Barite Hill, S.C.: Felsic volcanics, Lincolnton metadacite

- Haile, S.C.: Felsic volcanic and volcaniclastic tuffs of the Persimmon Fork Fm

- Gold Hill Fault, Albemarle, Howie, Reed, Russell, Champion Hills, N.C.: felsic volcanic and volcaniclastic tuffs of the Uwharrie Fm

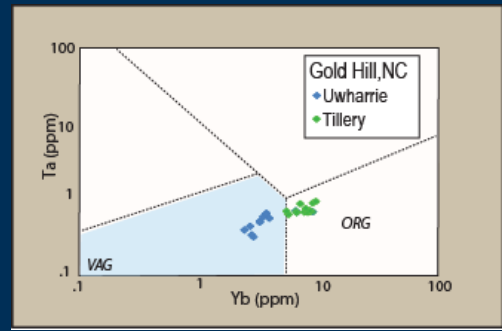

- Trends consistent with volcanic arc related signatures (VAG)

Figure 9. Plots of tantalum-ytterbium (Ta-Yb) for the Persimmon Fork Formation and regional equivalents.

These complexities make stratigraphic correlations in the region difficult, but the consensus is that the bulk of the rocks collectively represent a long-lived, mature arc system. An AFM diagram (fig. 8) shows that the Persimmon Fork is consistent with the expected calc-alkaline trend (Ayuso and others, 2005). Other trace element distributions (fig. 9) are also consistent with volcanic arc related signatures. For example, plots of $\mathrm{Ta}-\mathrm{Yb}$ show that the composition of the Persimmon Fork Formation at Haile, correlative felsic volcanic rocks at Barite Hill, and volcanic rocks of the Uwharrie in North Carolina are also consistent with volcanic arc related signatures (Ayuso and others, 2005; Glascock and Speakman, 2005). 


\section{Age of the Volcanic Host Rocks and Gold Deposits}

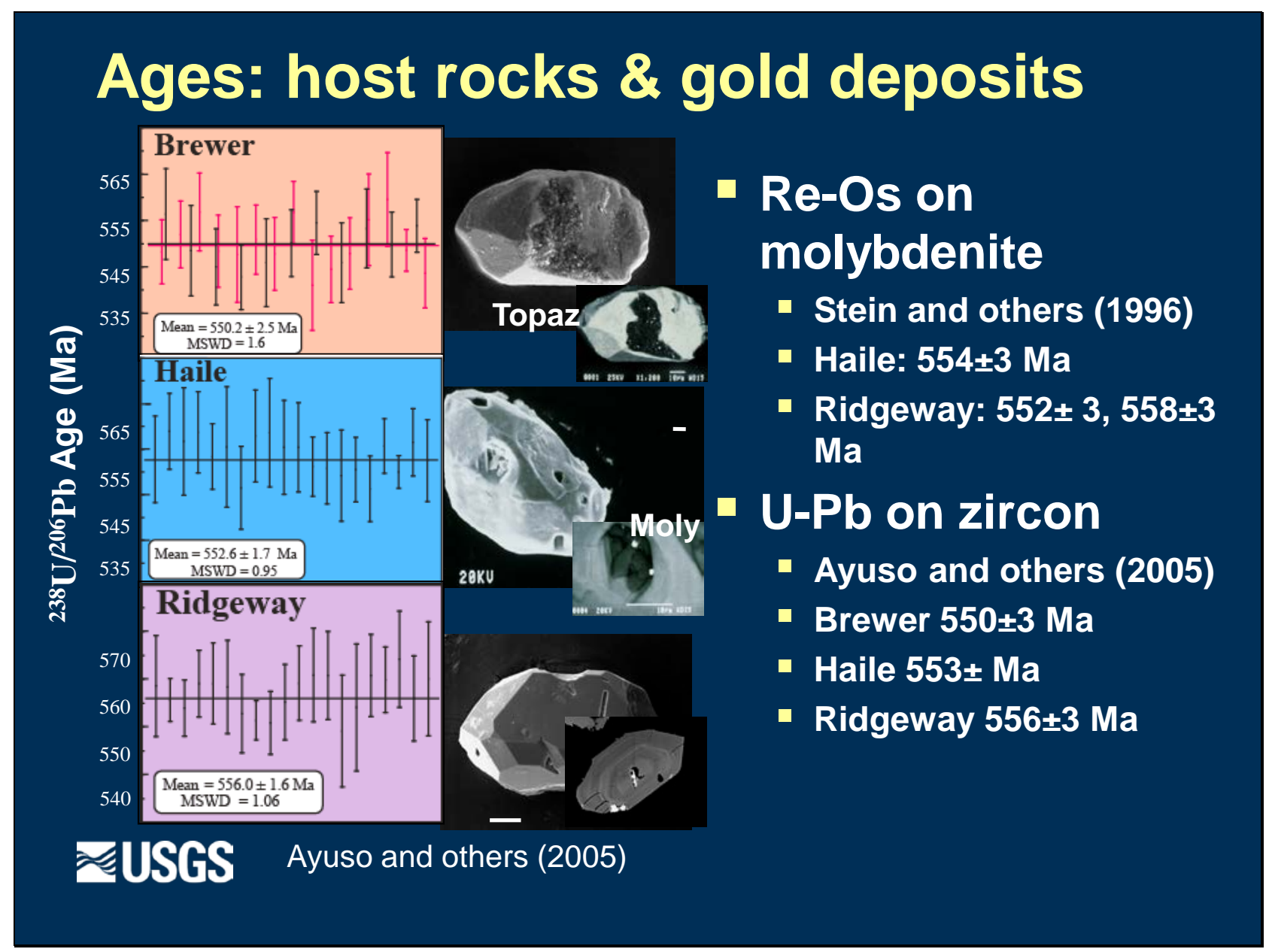

Figure 10. Age dating of host rocks and gold deposits of the Carolina Slate Belt.

There have been numerous attempts to date both the deposits and the immediate host rocks by using various techniques. The successful ones are Re-Os on molybdenite and U-Pb ion probe or SHRIMP data on zircon (fig. 10). The studies we completed on zircons at Haile, Ridgeway, and Brewer are especially useful because we were able to both date the host rocks and provide a link with the hydrothermal event that resulted in gold mineralization by looking closely at the zircon populations (Ayuso and others, 2005). What is interesting is that the zircon populations analyzed show imperfections that indicate hydrothermal etching or recrystallization related to early stages of mineralization. For example, the age of subvolcanic intrusive at Brewer is $550 \mathrm{Ma}$. At Brewer, zircon is encrusted and replaced by topaz that formed during an early alteration stage associated with gold mineralization. Likewise, at Haile the age of the volcanic host is $553 \mathrm{Ma}$. The pits and cavities in zircon from Haile contain muscovite flakes and small crystals of molybdenite that are prominent in the alteration and mineral assemblages, so we think that the zircon crystallization ages are closely linked to early stages of mineralization. These zircon ages line up well with Re-Os ages on molybdenite from the Haile and Ridgeway deposits as measured by Stein and others (1996).

New age-information on subvolcanic-intrusion-related mineralization near Deep River, N.C., (Rapprecht, 2010) also supports an age of 550 Ma for felsic dikes that cut rocks of the Virgilina 
sequence and are thought to be equivalent to rocks of the Uwharrie Formation. Molybdenite (Rapprecht and others, 2010) from the Deep River prospect is dated at $543 \mathrm{Ma}$ and $532 \mathrm{Ma}$, suggesting a younger, Cambrian-age, mineralizing event.

\section{Mineralogy and Textures of Selected Gold Deposits}

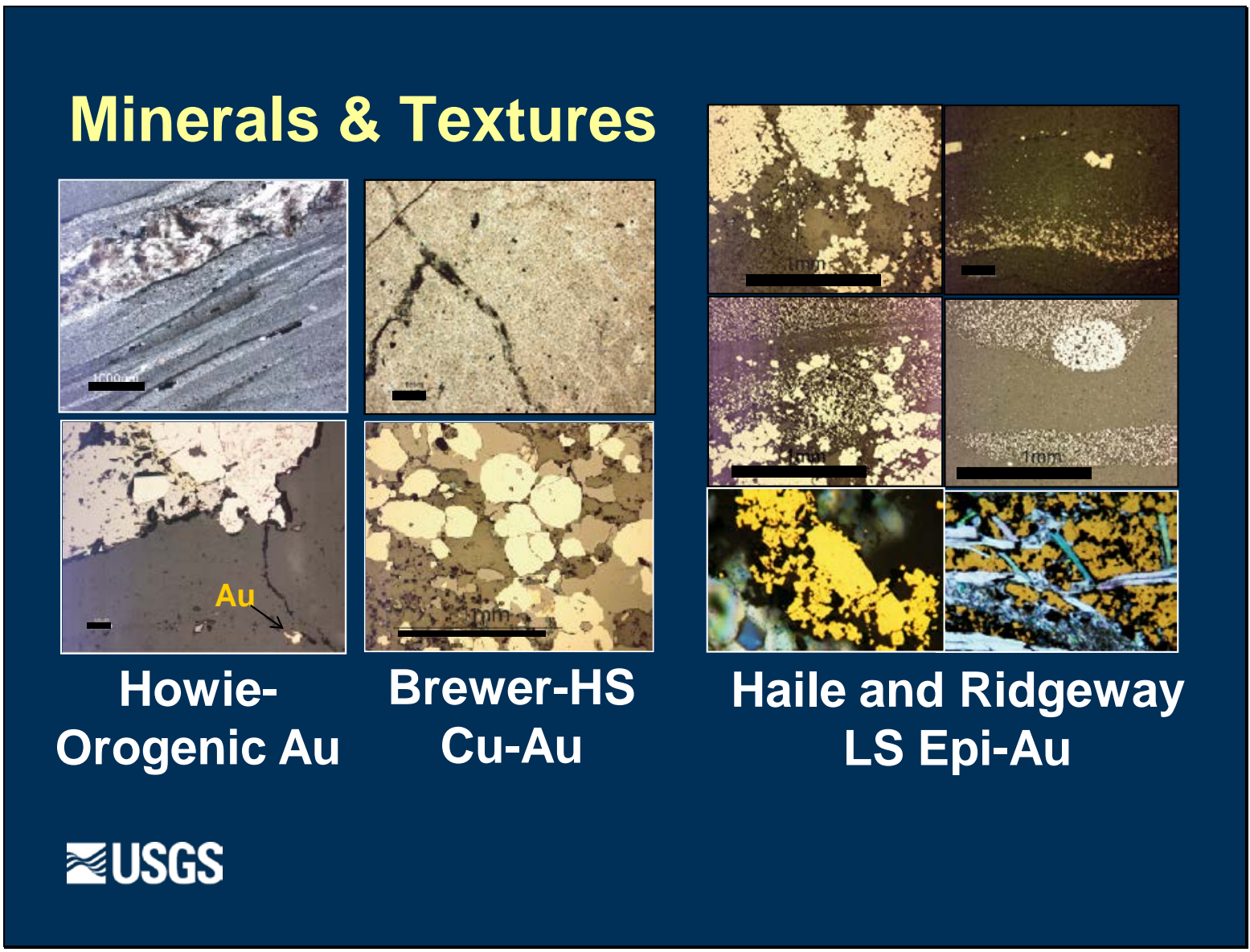

Figure 11. Mineralogies and textures of three types of selected gold deposits in the Carolina Slate Belt.

Figure 11 shows the distinctive mineralogies and textures of three types of gold deposits in the Slate Belt: shear-zone hosted orogenic-style mineralization, high sulfidation (HS) epithermal gold mineralization, and low sulfidation (LS) epithermal gold mineralization.

Gold deposits occurring along late Ordovician shear zones, which are related to docking of the Carolina terrane to the Charlotte terrane and accretion of the Carolina zone to the eastern margin of Laurentia, include the Howie mine, North Carolina (fig. 11, left column). In these deposits, the sulfides and quartz are recrystallized and gold is associated with massive quartz veins containing pyrrhotite and pyrite and other base metal sulfides, including arsenopyrite (N.K. Foley, unpublished data, 2012).

In contrast, high-sulfidation epithermal gold deposits of the Slate Belt, of which Brewer may be a unique example, can be expected to have a classic enargite-pyrite-chalcopyrite-gold assemblage (fig. 11, center column) (Foley and others, 2007). Minor covellite is also present. The alteration assemblages, including andalusite, topaz, and pyrophyllite, are consistent with those expected for highsulfidation acid-sulfate-style systems. The sulfides form in structure-controlled massive veins and as cements for sulfide breccias. As shown in the thin section photograph, the sulfide minerals are coarser 
grained, more equant, and intergrown compared to textures for the other epithermal gold deposits. The sulfide minerals of the high-sulfidation system at Brewer are really texturally quite distinct from the finer grained, almost sedimentary-style bedded and layered textures that characterize the large lowsulfidation epithermal-gold deposits that are found nearby at Haile and Ridgeway (fig. 11, right panel). At Haile and at Ridgeway, gold is associated with both quartz and pyrite. Pyrite dominates the sulfide mineralogy and only very minor amounts of base metal sulfides are present. These include sphalerite, galena, pyrrhotite, chalcopyrite, and molybdenite; gold and silver tellurides are also present. The pyrite is disseminated to semi-massive, and it occurs as colloform stringers, layers, and replacements in banded tuffaceous ash flow; many of the layers have soft-sediment-style textures, including graded beds and reworked sulfide sediment. The feldspar-stable alteration assemblage includes sericite, illitesmectite, adularia, and kaolinite (Foley and others, 2000). (All photographs by N.K. Foley, unpublished data, 2012.)

Metamorphic overprints obscure many of the original mineralogical and textural clues to genesis, although at Haile, in particular, there is ample evidence for the presence of early epithermal gold mineralization.

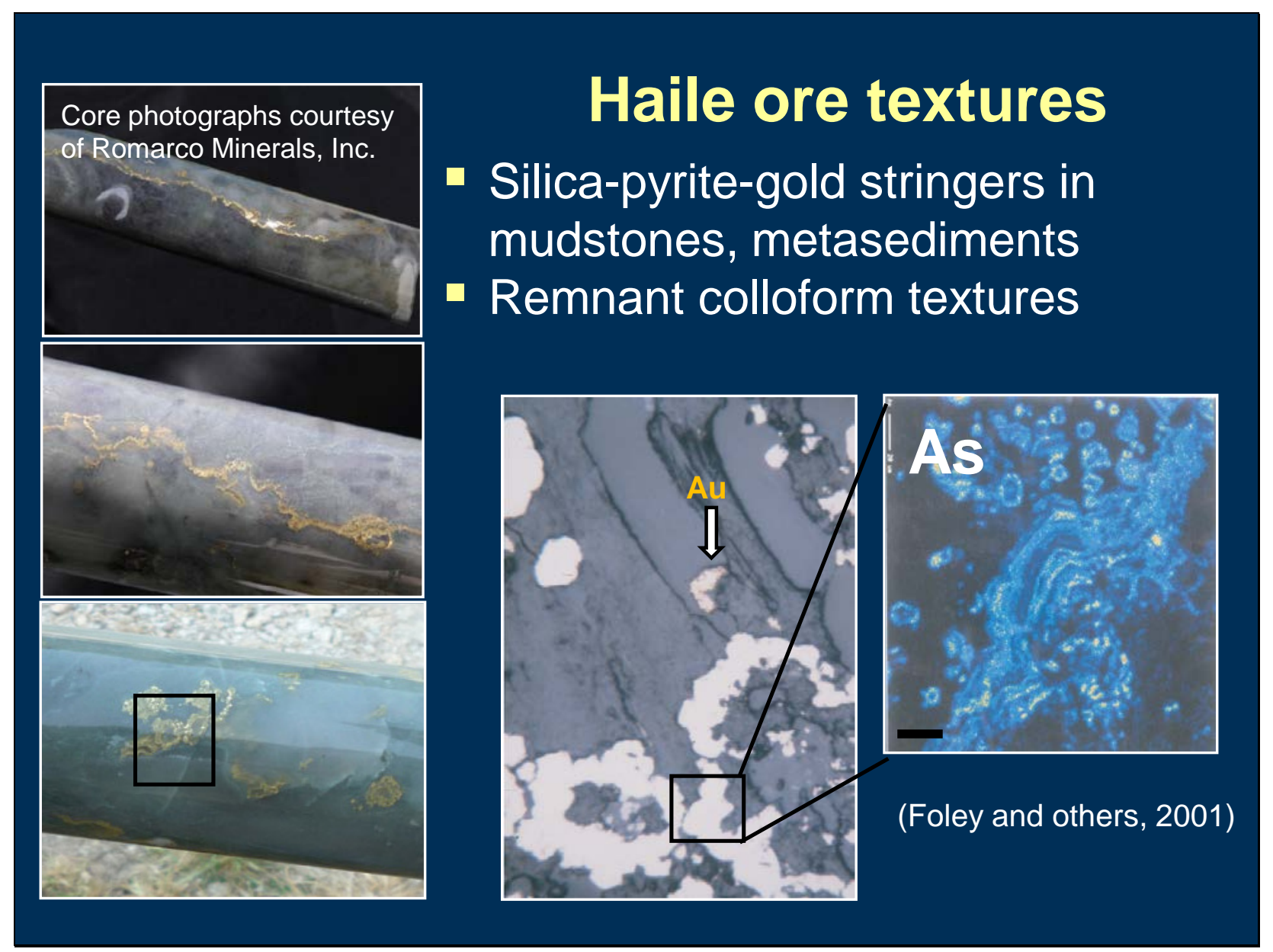

Figure 12. Evidence in ore textures for the presence of early epithermal gold mineralization.

Multiple generations of pyrite are in the deposits at Ridgeway and Haile; however, as shown in figure 12, gold is generally associated with early colloform pyrite, either in bands of milky fine 
chalcedonic quartz or in the pyrite layers themselves. This earlier study by Foley and others (2001) showed that much of the colloform pyrite has retained delicate arsenic zoning and blebs of electrum in a silicified matrix. Photographs of new core on the left, provided by Romarco Minerals Inc., show that this style of colloform gold-pyrite mineralization associated with massive amounts of cryptocrystalline silica also characterizes some of the new discoveries at Haile. The colloform structures are likely best preserved (from later periods of deformation) where the pyrite-gold layers are associated with massive siliceous pods and stockwork veining. Such colloform layering is characteristic of epithermal hot springs and bonanza-style mineralization formed by boiling of hydrothermal fluids (Saunders, 1990).

\section{Haile, early pyrite-gold textures}

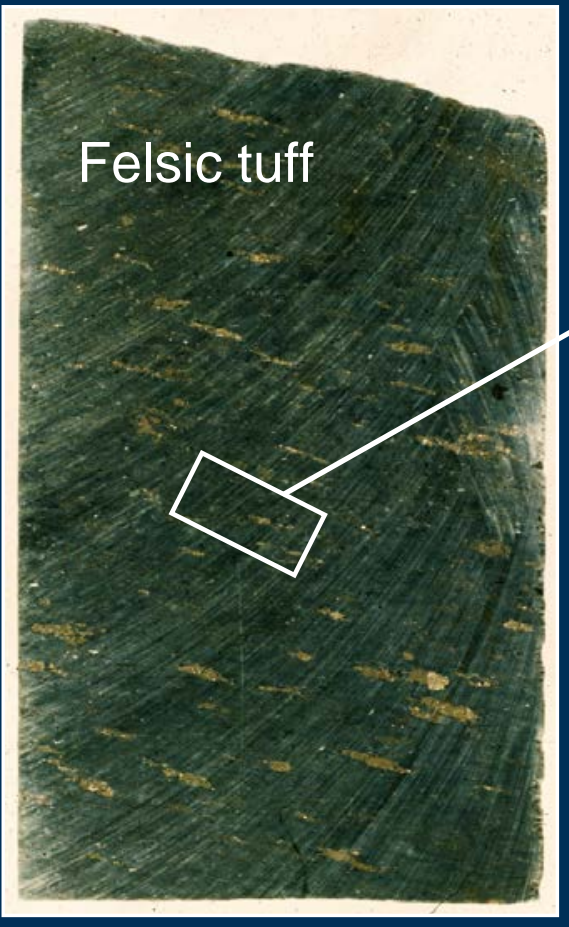

\section{- Replaced pumice, gold in pyrite}

(Foley and others, 2001)

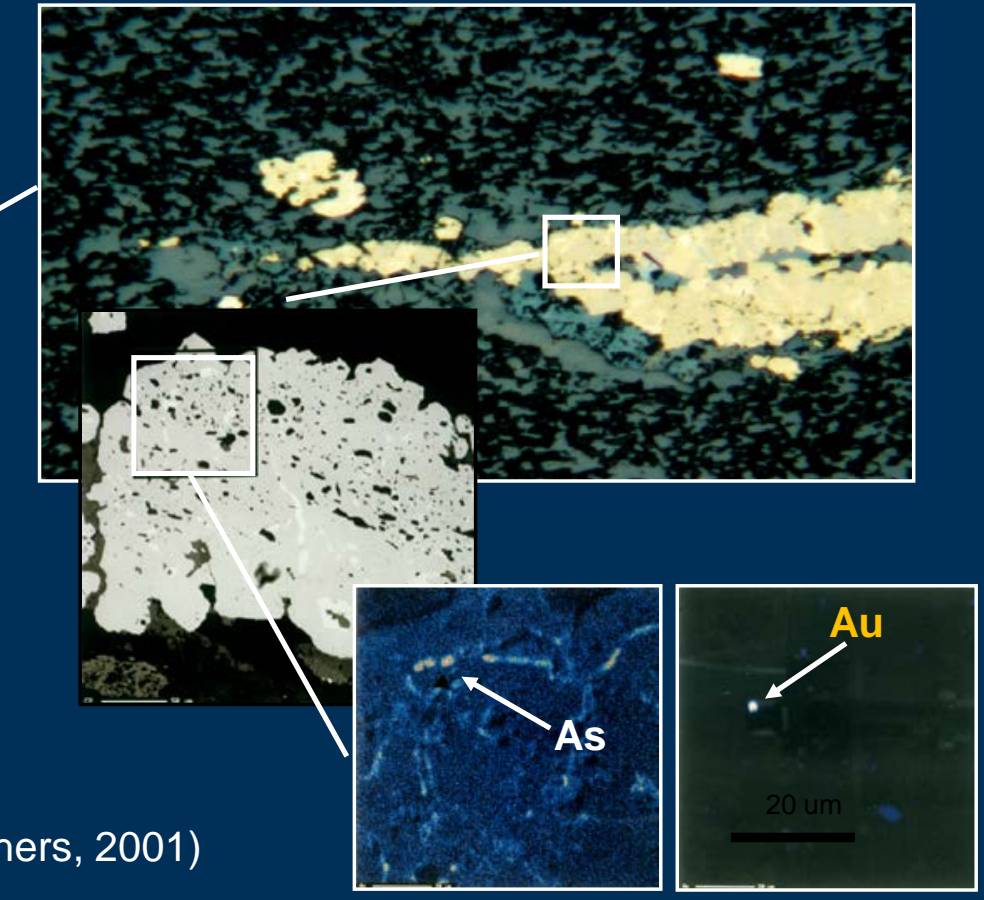

Figure 13. Evidence in volcanic rock textures for the presence of early epithermal gold mineralization.

Figure 13 shows another example of an early type of epithermal pyrite. This photograph shows a felsic tuff containing abundant flattened pumice that has been replaced by pyrite. This pyrite also contains delicate arsenic banding and micron-sized blebs of gold. One can envision a semi-lithified, incompletely welded and still somewhat permeable ashflow tuff being invaded by hydrothermal fluids capable of replacing the original flattened glassy pumice with pyrite, arsenic, and gold. 


\section{Fluid Chemistry}

\section{Fluid chemistry and Au deposition}

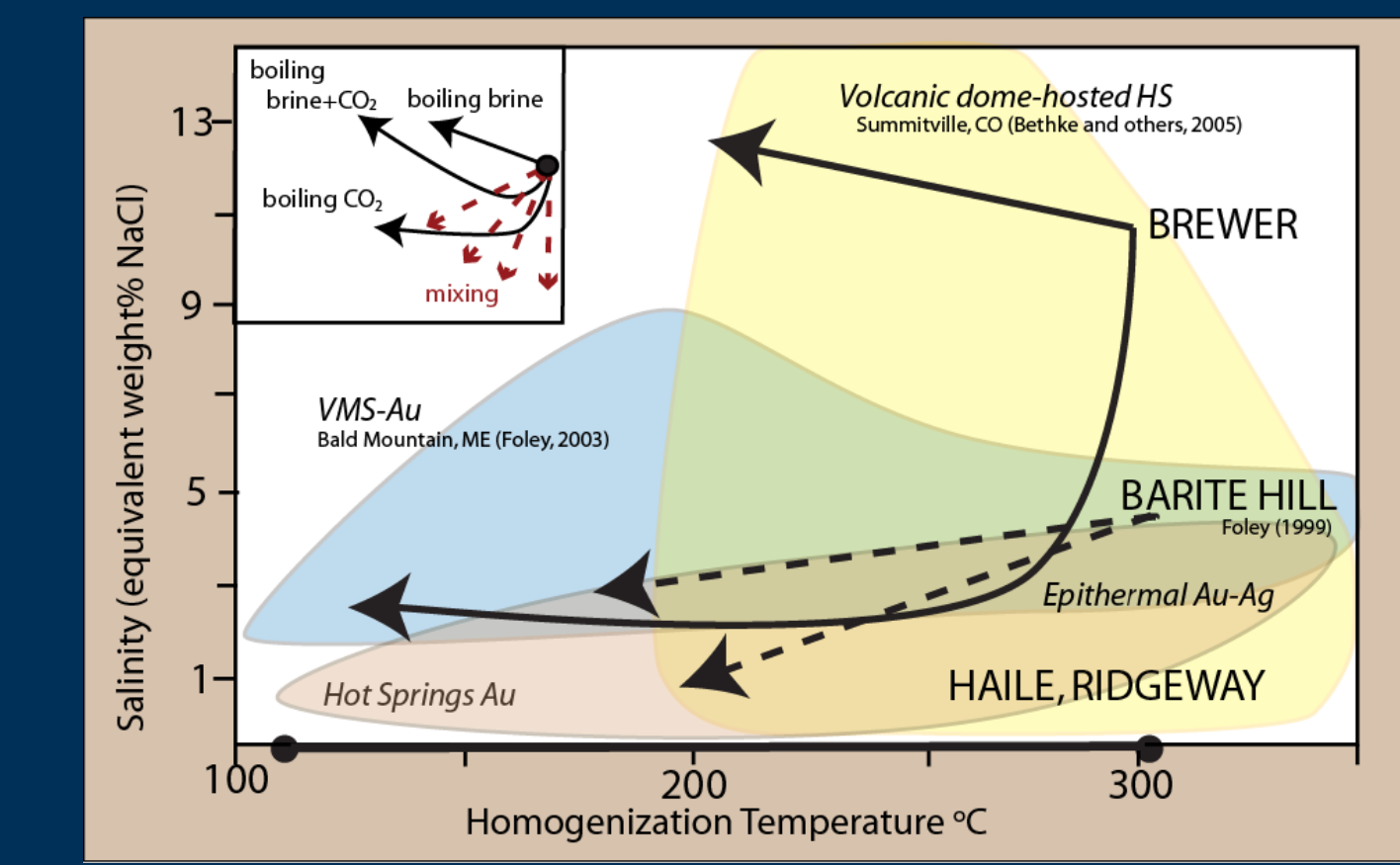

$\approx$ ¿USG

Foley and others (2007)

Figure 14. Fluid inclusion data for the major gold deposits compared to classic datasets for high- and lowsulfidation (HS, LS) epithermal deposits and gold-rich volcanogenic massive sulfide (VMS) deposits.

Trends in fluid inclusion data that I have collected for these deposits (Foley and others, 2007) are shown on figure 14 with fields for classic datasets for high- and low-sulfidation epithermal deposits (Bethke and others, 2005) and gold-rich volcanogenic deposits (Foley, 2003). The main point to be made here is that the data are consistent with typical epithermal-volcanogenic models for gold. At Barite Hill deposit, the trends support an origin by mixing of hydrothermal fluids and seawater and deposition at the sea floor (blue field). At Brewer, the trends show that the fluids contained a higher range in salinities (near 11 weight percent sodium chloride equivalent) and carbon dioxide contents that are consistent with ore deposition from subsurface boiling of fluids of various brine chemistries, as might be expected in association with subvolcanic intrusions (yellow field). For Ridgeway and Haile, the available data are limited to homogenization temperatures collected on a small number of inclusions. The data are not definitive, but the range (homogenization temperatures generally less than $300{ }^{\circ} \mathrm{C}$ ) is consistent with shallow epithermal deposits having hot springs and subaqueous boiling in the stockwork feeder zones (pink and orange fields). 


\section{Sulfur Isotope Data}

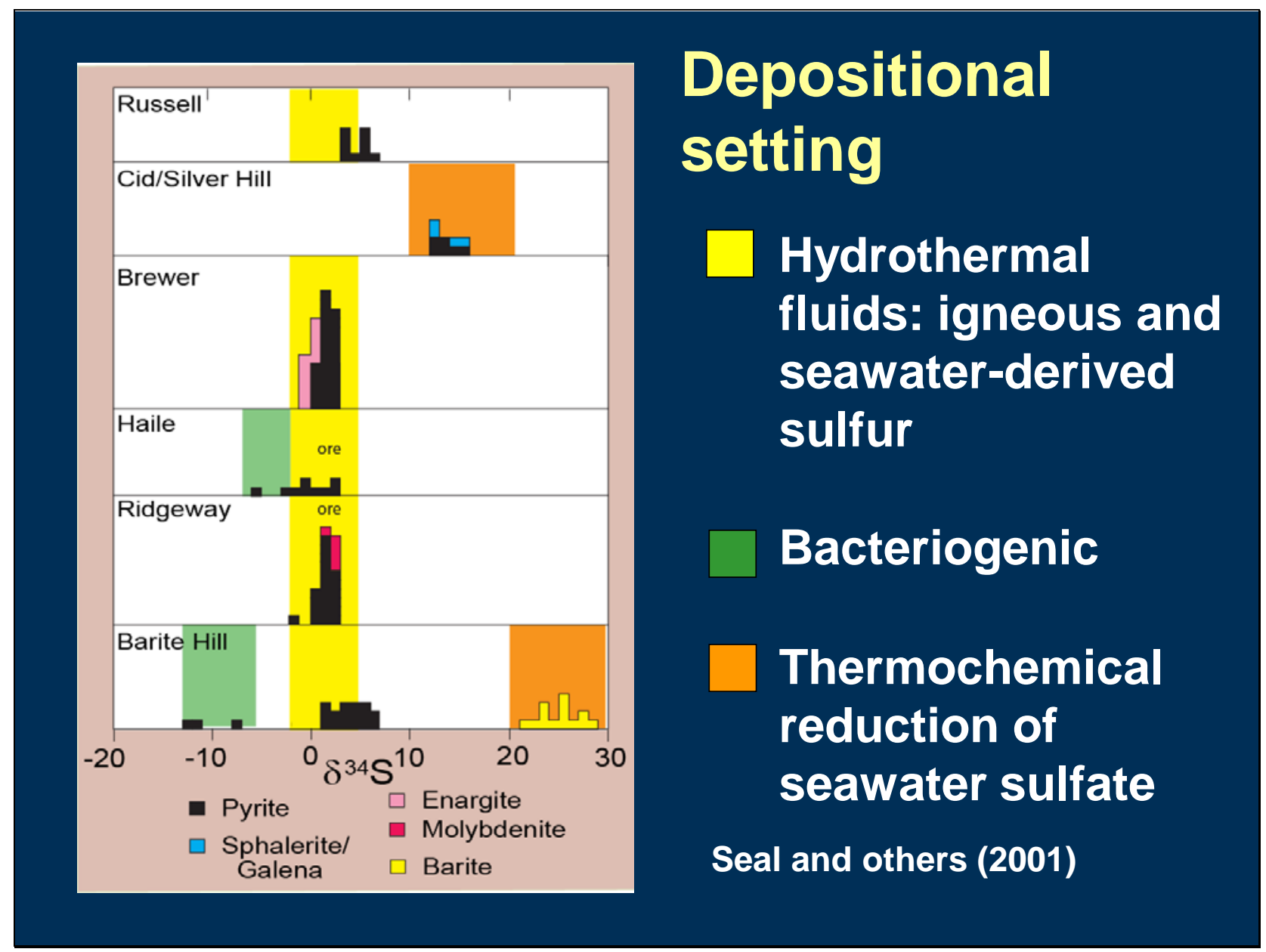

Figure 15. Sulfur isotope data for ore deposits of the Carolina Slate Belt.

Sulfur isotope data (Seal and others, 2001) provide additional information on the depositional setting of these ores. The major point we want to make here (fig. 15) is that the bulk of the sulfur data, which are shown in a yellow band on this figure, for all the deposits indicates hydrothermal fluids having significant igneous and seawater-derived sulfur, such as would characterize classic volcanogenic and volcanic-related submarine epithermal deposits. 


\section{Lead Isotope Data}

\section{Source of metals in host and ore}
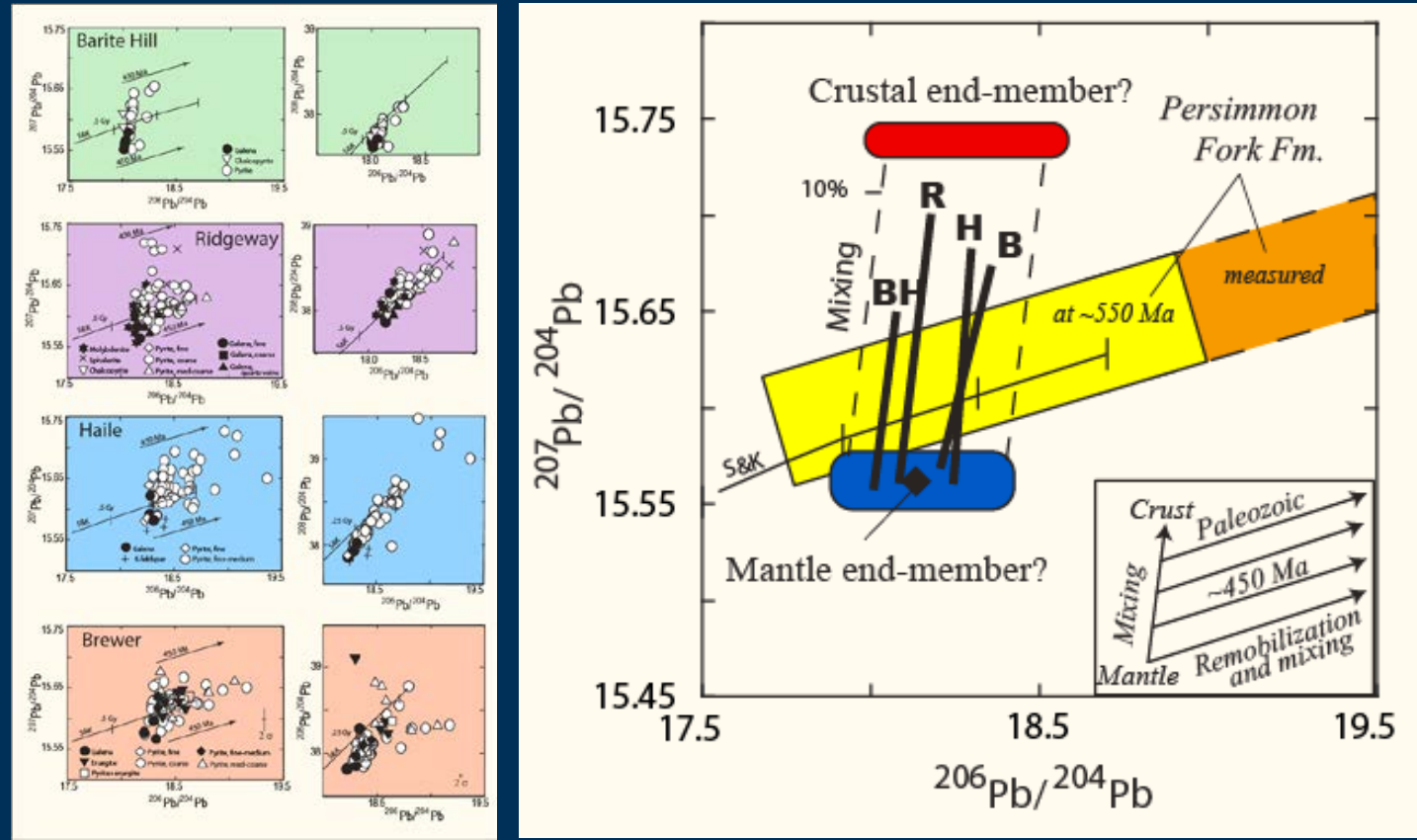

- Barite Hill (BH), Ridgeway (R), Haile (H) and Brewer (B)

\section{ZUSGS}

Ayuso and others (2005)

Figure 16. Lead isotope compositions for the gold deposit of the Carolina Slate Belt.

Lead isotope compositions for Brewer, Haile, Ridgeway, and Barite Hill (fig. 16) are shown on the left (Ayuso and others, 2005; Foley and others, 2007). This study included data for galena, potassium-feldspar, pyrite, chalcopyrite, molybdenite, quartz, sphalerite, and muscovite from both ore and host rock. On the figure on the right, I have replotted the trends for the data in heavy bars. The yellow field on this figure is lead data for the Persimmon Fork Formation corrected to 550 Ma. The Persimmon Fork Formation represents a mixture of mantle-derived (blue field) and crustal rocks (red field) and is a good match for lead in the deposits.

A couple of other items on this figure are noteworthy. There is a distinct geographic trend in lead isotope compositions for the gold deposits, with an increasing contribution of crustal lead moving from the Barite Hill deposits in the south to Haile and Brewer in the north. These changes in lead isotopic composition for ${ }^{206} \mathrm{~Pb} /{ }^{204} \mathrm{~Pb}$ reflect a thinned continental crust versus a rift environment. Another important distinction among the deposits is that Ridgeway and Haile, the two largest systems, and Brewer have higher ${ }^{207} \mathrm{~Pb} /{ }^{204} \mathrm{~Pb}$ compared to Barite Hill, also suggesting their sources included a higher proportion of a crustal endmember. 


\section{Neodymium Isotope Data}

\section{Source rocks: Nd isotope data}

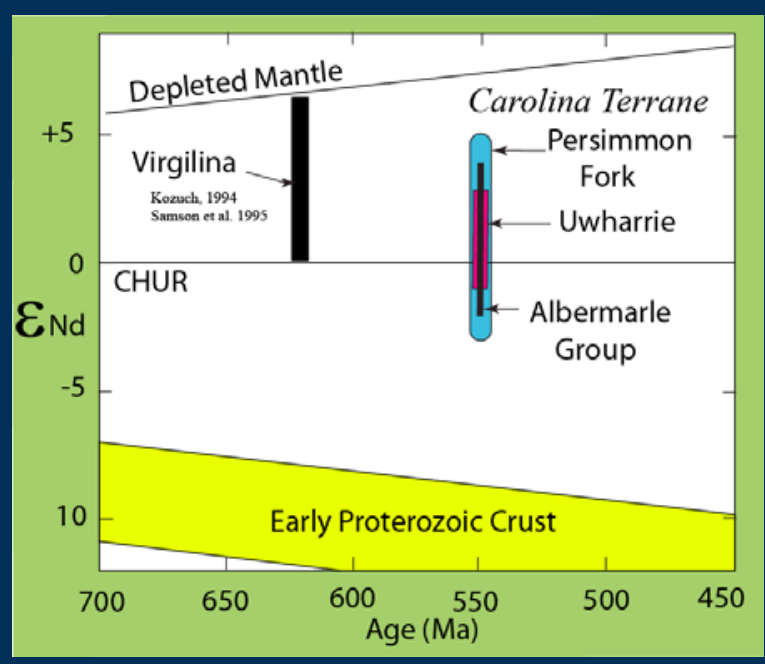

Carolina Terrane:

Albemarle sequence, a mature arc with involvement of a crustal component during magmatism

\section{₹USGS}

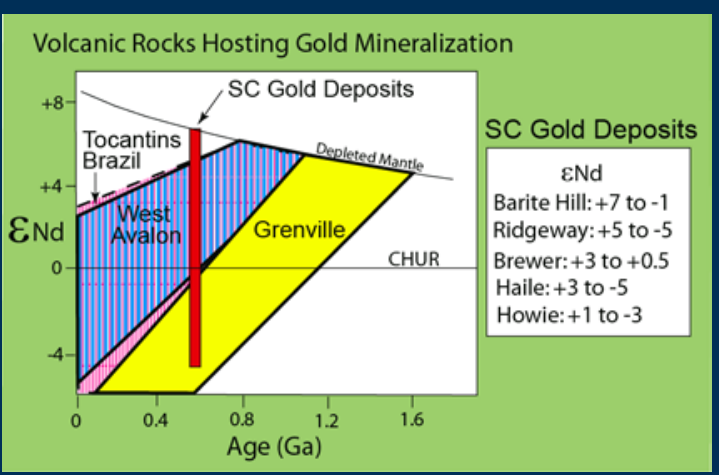

Gold deposits:

\section{Barite Hill - the highest mantle-derived contribution}

Ridgeway, Haile - highest crustal contribution

Ayuso and others (2005); Foley and others (2007)

Figure 17. Neodymium isotope data for host rocks and gold deposits of the Carolina Slate Belt.

The epsilon-Nd ( $\varepsilon N d)$ versus age plot on the left (fig. 17) shows two contrasting age and chemical groups of metavolcanic rocks in the Carolina terrane (Ayuso and others, 2005). The older Virgilina sequence (са. $650 \mathrm{Ma}$ ) was derived from juvenile and mantle sources, whereas the younger Albemarle sequence (ca. 570-540 Ma), which includes the broadly correlative Persimmon Fork and Uwharrie Formations, indicates a mature arc that involved a continental crustal component.

Neodymium isotope compositions also show differences that help to explain the metallogenic contrasts among the deposits. For example, Ridgeway and Haile have the highest crustal contribution ( $\varepsilon N d{ }_{554} \sim+5$ to -5 , crustal residence $\sim 0.7-1.9 \mathrm{Ga}$ ). In contrast, Barite Hill, the closest analogue to a classical volcanogenic massive sulfide, has the highest mantle-derived contribution ( $\varepsilon \mathrm{Nd}_{554} \sim+7$ to -1 ; crustal residence $\sim 0.7-1.2 \mathrm{Ga}$ ). Thus, both the lead and $\varepsilon N d$ isotope signatures are consistent with a relatively mature arc that involved a continental crustal component for Ridgeway, Haile, and Brewer (a thinned continental crust) and a rift environment at Barite Hill (Ayuso and others, 2005; Foley and others, 2007). 


\section{Recent Exploration Efforts in the Region}

Recent exploration and drilling by a number of companies have identified new areas having potential for significant gold tonnages in the Carolina Slate Belt.

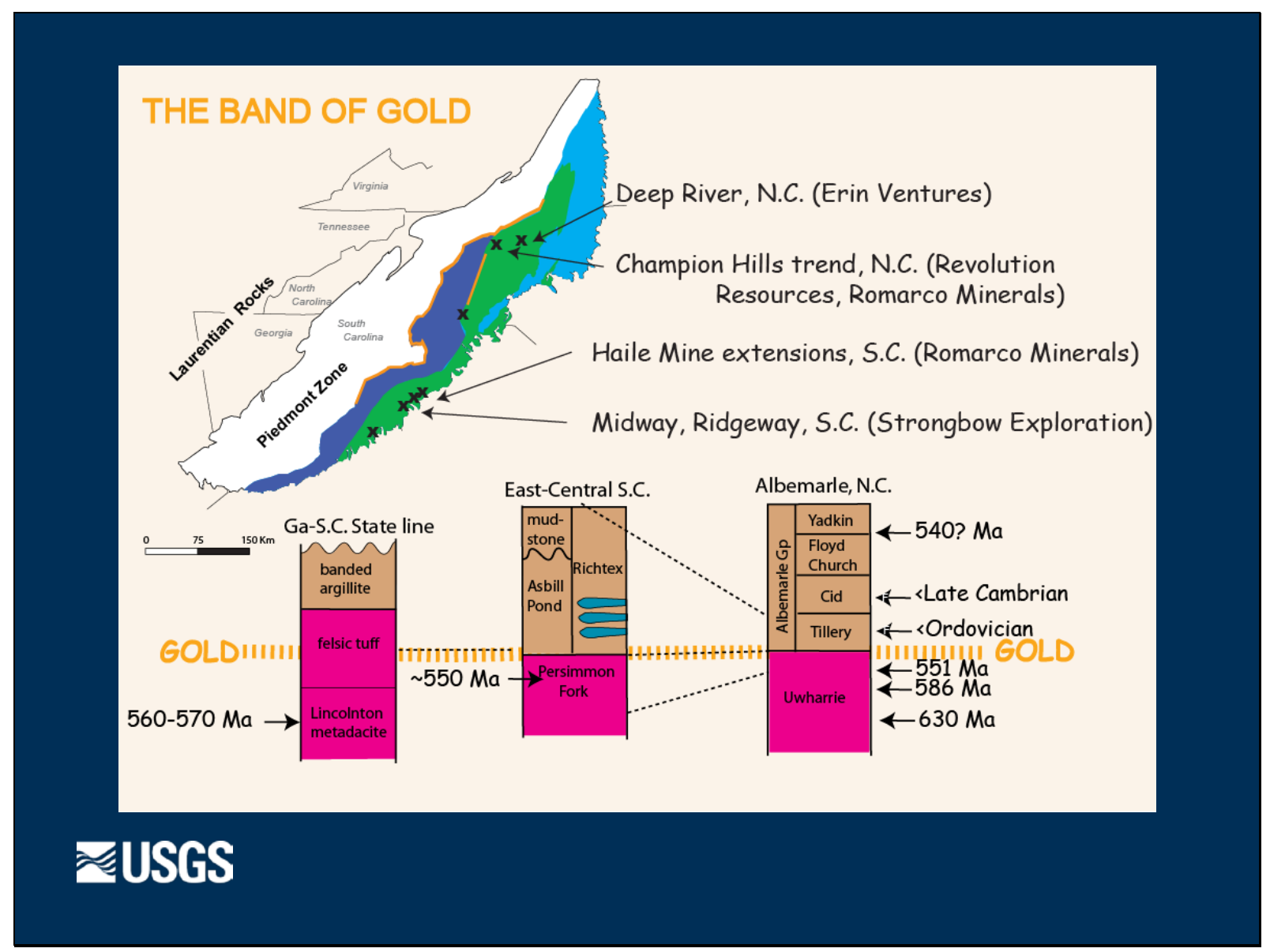

Figure 18. Locations of recent exploration and drilling by companies referred to in the text.

These properties include, from north to south (fig. 18):

1. The Deep River prospect in central North Carolina: Erin Ventures, Inc., has described an occurrence of shallowly emplaced porphyry-style mineralization having gold, copper, and molybdenum signatures (http://www.erinventures.com/presentation/deepriver.php).

2. The Champion Hills trend in central North Carolina: Revolution Resources Corp. (http://revolutionresourcescorp.com/properties/north_carolina_project/carolina_slate_belt/) and Romarco Minerals Inc. (http://www.romarco.com/Our-Projects/New-Regional-Targets/default.aspx) delineated a number of targets along a 25-kilometer-long mineralized trend with similarities to the Haile-Brewer Slate Belt trend.

3. The Haile Gold Mine in east-central South Carolina: Romarco Minerals Inc. has demonstrated that significant potential exists in the Slate Belt with the discovery of a new zone (Horseshoe) early in 2010 and two new zones (Mustang and Palomino) that confirm an underground potential at Haile. Romarco Minerals is continuing to delineate and define the Horseshoe area as well as continuing to 
expand the mineralized corridor, which is thought to remain open in all directions and at depth with the discovery of the new high-grade zones having underground mining potential. Also, Romarco Minerals is extending its regional assessment of the area, recognizing that Haile is part of a much larger gold district. Plans are underway to open the new Haile mine; site construction is in progress. The Haile mine is online to begin gold production in the next few years (http://www.romarco.com/Our-Projects/Haile/Haile-Overview/default.aspx).

4. Strongbow Exploration Inc. is currently looking at two attractive areas. At the Midway project (http://www.strongbowexploration.com/s/Midway.asp), located between Haile and Brewer along the gold trend, drilling and exploration reportedly revealed notable gold, molybdenum, and copper anomalies. The second area is near Ridgeway where the mining company has delineated an area of potential gold mineralization concealed under Coastal Plain sediments (http://www.strongbowexploration.com/s/ridgeway.asp).

Many of these targets and resources have been found by applying more modern geophysical and geochemical mapping techniques that make it easier to target potentially high-grade areas.

These discoveries are particularly significant because they confirm genetic models based on epithermal gold styles of mineralization, where one expects to find large tonnage, low-grade disseminated gold deposits with potentially high-grade feeder zones. The discovery of new zones in established districts, such as Haile, at depth, and along the trend of the Slate Belt suggests that many similar deposits may remain open in all directions as well. This supports the possibility of additional larger, low-grade gold deposits and potentially high-grade feeder zones at Ridgeway, for example, and substantiates exploration models based on concepts that point to the existence of relatively long-lived, large-scale gold mineralizing systems.

\section{Summary}

Table 2. Age and origin of deposits of the Carolina Slate Belt.

[S.C., South Carolina; N.C., North Carolina, Au, gold; HS, high sulfidation; Epi-Py-En-Au, epithermal-pyriteenargite-gold; LS, low sulfidation; PFF, Persimmon Fork Formation; VMS, volcanogenic massive sulfide; ?, age unknown; <, less than; , approximately]

\begin{tabular}{|c|c|c|c|}
\hline Deposit & Model/style & Host Rock/Age & Deposit Age \\
\hline Brewer placers & Placer-Au & $\mathrm{PFF} / 550$ & $<$ Late Paleozoic \\
\hline $\begin{array}{l}\text { Howie, Gold Hill Shear } \\
\text { Zone }\end{array}$ & Shear-zone, orogenic -Au & PFF, Uwharrie & Late Paleozoic \\
\hline Brewer, S.C. & $\begin{array}{l}\text { HS, Epi-Py-En-Au porphyry, } \\
\text { subvolcanic }\end{array}$ & $\mathrm{PFF} / 550$ & 550 \\
\hline $\begin{array}{l}\text { Russell mine, North } \\
\text { Carolina }\end{array}$ & LS, Epi-Py-Au & $\begin{array}{l}\text { Tillery (related to rhyolite } \\
\text { dome)/ ? }\end{array}$ & ? \\
\hline Deep River, N.C. & $\begin{array}{l}\text { LS, Epi-Py-Au, subvolcanic } \\
\text { intrusive? }\end{array}$ & $\begin{array}{l}\text { Virgilina (related to felsic } \\
\text { dike)/550 }\end{array}$ & $543-532$ \\
\hline $\begin{array}{l}\text { Champion Hills trend, } \\
\text { North Carolina }\end{array}$ & $\begin{array}{l}\text { LS, Epi-Py-Au, subvolcanic } \\
\text { intrusive? }\end{array}$ & Uwharrie/? & ? \\
\hline $\begin{array}{l}\text { Haile deposits, South } \\
\text { Carolina }\end{array}$ & LS, Epi-Py-Au & PFF/553 Richtex/? & 554 \\
\hline Barite Hill, S.C. & $\mathrm{Au}-\mathrm{VMS}$ & Lincolnton/566 & $\sim 566$ \\
\hline
\end{tabular}


Table 2 summarizes some of our current understanding of the age and origin of the largest deposits of the Carolina Slate Belt. The largest deposits occur in late Neoproterozoic basins that are volcanic arc-related with evidence for a thinned continental crust. A major influx of gold mineralization across the Slate Belt at about $550 \mathrm{Ma}$ is generally coeval with mature arc-related volcanism dated at 556-550 Ma. Epithermal gold mineralization could potentially have occurred over an interval of millions of years at different locations within the Slate Belt (considering the errors associated with the various age dates), although the duration of mineralization at any one deposit or site was probably significantly shorter. Estimates of the duration of single epithermal systems typically range from less than 50,000 years to no more than a few 100,000 years, without replenishment of the heat source. New evidence suggests arc magmatism in the Carolina zone continued into the Cambrian, and there is also evidence in some new age-dating for gold mineralization (Rapprecht, 2010) occurring in at least one part of the Slate Belt in the Early Cambrian as well.

The dominant style of mineralization in the Carolina Slate Belt is base-metal-poor, lowsulfidation epithermal gold, related to calc-alkaline volcanic rocks; however, a high-sulfidation subvolcanic phase of mineralization is present at Brewer that is generally coeval with the lowsulfidation assemblages at Haile. The presence of high-sulfidation assemblages at Brewer is evidence for the potential occurrence of porphyry copper-gold deposits at depth, unless a form of tectonic quenching (for example, Einaudi and others, 2003) such as might result from, for example, large-scale crustal faulting or rapid uplift and erosion, has separated the shallow high-sulfidation subvolcanic epithermal deposits from porphyry roots or suppressed their development. The occurrence of lowsulfidation gold deposits together with high-sulfidation gold mineralizing systems goes against standard conjecture that high-sulfidation deposits are commonly associated, both spatially and temporally, with intermediate sulfidation deposits in arc terranes (Sillitoe and Hedenquist, 2003). Calc-alkaline rhyolitic rocks and associated low-sulfidation epithermal deposits, especially those formed in back-arc, riftrelated settings, are generally thought to lack appreciable high-sulfidation gold deposits and have only tentative links to deep magmatic systems (Sillitoe and Hedenquist, 2003). The Carolina Slate Belt may well exemplify the most prospective example of the occurrence of low-sulfidation subaerial to shallow submarine epithermal deposits formed in an ancient, relatively immature magmatic-arc setting where the presence of coeval (or superimposed) high-sulfidation gold deposits may establish a close link to potential porphyry copper-gold roots.

The Carolina Slate Belt is a highly prospective belt of rocks with a potential for containing additional undiscovered deposits of gold and copper and other metals. We want to thank the organizers of the Prospectors and Developers Association for inviting us to give this presentation in this session on Mining in the United States.

\section{References Cited}

Ayuso, R.A., Wooden, J.L., Foley, N.K., Seal, R.R., II, Sinha, A.K., 2005, U-Pb zircon ages and Pb isotopic geochemistry of gold deposits in the Carolina Slate Belt of South Carolina: Economic Geology, v. 100, p. 225-252.

Bethke, P.M., Rye, R.O., Stoffregen, R.E., Vikre, P.G., 2005, Evolution of the magmatic-hydrothermal acid sulfate system at Summitville, Colorado-Integration of geological, stable-isotope, and fluid inclusion evidence: Chemical Geology, v. 215, p. 281-315.

Clark, S.H.B., Gray, K.J., Back, J.M., 2000, Geology of the Barite Hill gold-silver deposit in the southern Carolina slate belt: Economic Geology, v. 94, p. 1329-1346. 
Dennis, A.J., and Shervais, J., 1993, Arc rifting of the Carolina terrane in northwestern South Carolina: Geology, v. 19, p. 226-229.

Dennis, A.J., Shervais, J.W., Mauldin, J., Maher, H.D., and Wright, J.E., 2004, Petrology and geochemistry of Neoproterozoic volcanic arc terranes beneath the Atlantic Coastal Plain, Savannah River site, South Carolina: Geological Society of America Bulletin, v. 116, p. 572-593.

Dennis, A.J., and Wright, J.E., 1997, The Carolina terrane in northwestern South Carolina, USA-Age of deformation and metamorphism in an exotic arc: Tectonics, v. 16, p. 460-473.

Dubè, B., Dunning, G., Lauziere, K., 1998, Geology of the Hope Brook mine, Newfoundland, Canada-A preserved Late Proterozoic high-sulfidation epithermal gold deposit and its implications for exploration: Economic Geology, v. 93, p. 405-436.

Einaudi, M.T., Hedenquist, J., and Inan, E.E., 2003, Sulfidation state of fluids in active and extinct hydrothermal systems - The porphyry-epithermal transition and beyond: Society of Economic Geologists Special Publication 10, p. 283-313.

Feiss, G.P., Vance, R.K., and Wesolowski, D.J., 1993, Volcanic rock-hosted gold and base metal mineralization associated with Neoproterozoic-Early Paleozoic back-arc extension in the Carolina terrane, southern Appalachian Piedmont: Geology, v. 21, p. 439-442.

Foley, N.K., 2003, Thermal and chemical evolution of ore fluids and massive sulfide mineralization at Bald Mountain, Maine, in Goodfellow, W.D., McCutcheon, S.R., and Peter, J.M., eds., Volcanogenic massive sulfide deposits of the Bathurst District and northern Maine: Economic Geology Monograph 11, p. 549-565.

Foley, N.K., Ayuso, R.A., and Seal, R.R., II, 2001, Remnant colloform pyrite at the Haile gold deposit, South Carolina-A textural key to genesis: Economic Geology, v. 96, p. 891-902.

Foley, N.K., Ayuso, R.A., and Seal, R.R., II, 2007, Gold deposits in the Avalonian tectonic zone of the southeastern United States; $9^{\text {th }}$ Biennial Meeting of the Society for Geology Applied to Ore Deposits, Mineral Exploration and Research: Digging Deeper, v. 1, p. 699-703.

Foley, N.K., Ayuso, R.A., Seal, R.R., II, Offield, T.W., Wooden, J.N., and Sinha, A.K., 2000, Mineralogical evidence for the age and origin of disseminated gold-iron-sulfide deposits of the Carolina slate belt, USA [abs.]: Geological Society of America Abstracts with Programs, v. 32, p. A17.

Galley, A.G., Hannington, M.D., and Jonasson, I.R., 2007, Volcanogenic massive sulphide deposits, in Goodfellow, W., ed., Mineral deposits of Canada-A synthesis of major deposit types, district metallogeny, and the evolution of geological provinces, and exploration methods, 5: St. Johns, Geological Association of Canada, Mineral Deposits Division, Special Publication 5, p. 141-162.

Gillon, K.A., Mitchell, T.L., Dinkowitz, S.R., Barnett, R.L., 1998, The Ridgeway gold deposits-A window to the evolution of a Neoproterozoic intra-arc basin in the Carolina terrane, South Carolina: South Carolina Geology, 40, p. 29-70.

Gillon, K.A., Spence, W.H., Duckett, R.P., and Benson, C.J., 1995, Geology of the Ridgeway gold deposits, Ridgeway, South Carolina: Society of Economic Geologists Guidebook Series, v. 24, p. 5394.

Glascock, M.D., and Speakman, R.J., 2005, Analysis of metavolcanic rocks from the vicinity of Fort Bragg, North Carolina-Comparing the results obtained by NAA, XRFA, and ICPMS: Accessed online at http://rla.unc.edu/bragg/P2L.Glascock.2005-01-06.pdf, January 9, 2012.

Goldfarb, R.J., Bradley, D., and Leach, D.L., 2010, Secular variations in economic geology: Economic Geology, v. 105, p. 459-465. 
Groves, D.I., Condie, K.C., Goldfarb, R.J., Hronsky, J.M.A., and Vielreicher, R.M., 2005, Secular changes in global tectonic processes and their influence on the temporal distribution of gold-bearing mineral deposits: Economic Geology, v. 100, p. 203-224.

Heald, P., Foley, N.K., and Hayba, D.O., 1987, Comparative anatomy of volcanic-hosted epithermal deposits_-Acid sulfate and adularia-sericite types: Economic Geology, v. 82, p. 1-26.

Hibbard, J., Miller, B., Tracy, R., and Carter, B., 2005, The Appalachian peri-Gondwanan realm-A paleogeographic perspective from the south, in Vaughan, A., and Leat, P., eds., Terrane Processes at the Pacific Margin of Gondwana: Geological Society [London] Special Publication 246, p. 97-112.

Hibbard, J., Standard, I., Miller, B., Hames, W., and Lavallee, S., 2003, Regional significance of the Gold Hill fault zone, Carolina zone of North Carolina: Geological Society of America Abstracts with Programs, v. 35, no. 1, p. 24.

Hibbard, J., Stoddard, E., Secor, D., and Dennis, A., 2002, The Carolina zone-Overview of Neoproterozoic to early Paleozoic peri-Gondwanan terrane along the eastern flank of the southern Appalachians: Earth-Science Reviews, v. 57, p. 299-339.

Hibbard, J.P., van Staal, C.R., and Miller, B.V., 2007, Links among Carolinia, Avalonia, and Ganderia in the Appalachian peri-Gondwanan realm: Geological Society of America Special Paper 433, p. 291311.

Hibbard, J.P., van Staal, C.R., and Rankin, D.W., 2010, Comparative analysis of the geological evolution of the northern and southern Appalachian orogen: Late Ordovician-Permian GSA Memoirs 2010, v. 206, p. 51-69.

John, D.A., 2001, Miocene and early Pliocene epithermal gold-silver deposits in the northern Great Basin, western United States-Characteristics, distribution, and relation to magmatism: Economic Geology, v. 96, p. 1827-1853.

Klein, T.L., Cunningham, C.G., Logan, M.A.V., and Seal, R.R., II, 2007, The Russell gold deposit, Carolina Slate Belt, North Carolina: Economic Geology, v. 102, p. 239-256.

Kozuch, M., 1994, Age, isotopic, and geochemical characterization of the Carolina slate and Charlotte belts - Implications for stratigraphy and petrogenesis: Unpublished M.S. thesis, Gainesville, Florida, University of Florida, 114 p.

Maddry, J.W., and Kilbey, T.R., 1995, Geology of the Haile gold mine: Society of Economic Geologists Guidebook Series, v. 24, p. 147-172.

Milton, D., 1984, Revision of the Albemarle Group, North Carolina: U.S. Geological Survey Bulletin 1537-A, p. 69-72.

Murphy, J.B., Keppie, J.D., Dostal, J., Nance, R.D., 1999, Neoproterozoic-Early Paleozoic evolution of Avalonia: Geological Society of America Special Paper 336, p. 253-265.

Mutschler, F.E., Mooney, T.C. 1993, Precious-metal deposits related to alkalic igneous rocksProvisional classification, grade-tonnage data and exploration frontiers, in Kirkham, R.V., Sinclair, W.D., Thorpe, R.I., Duke, J.M., eds., Mineral deposit modeling: Geological Association of Canada Special Paper 40, p. 479-520.

Pollock, J.C., and Hibbard, J.P., 2009, Geochemistry and tectonic significance of the Stony Mountain gabbro, North Carolina-Implications for the Early Paleozoic evolution of Carolinia: Gondwana Research Volume 17, Issues 2-3, March 2010, p. 500-515.

Pollock, J.C., Hibbard, J.P., and Sylvester, P.J., 2010, Depositional and tectonic setting of the Neoproterozoic-early Paleozoic rocks of the Virgilina sequence and Albemarle Group, North Carolina: Geological Society of America Memoirs, v. 206, p. 739-772. 
Rapprecht, R.M., 2010, A study of Late-Proterozoic host rocks, the style of mineralization and alteration, and their timing at the Deep River gold prospect, central North Carolina: Masters Abstracts International, v. 49, no. 02, 117 p.

Rapprecht, Rachel, Stewart, K.G., and LaPoint, Dennis, 2010, A study of late-Proterozoic host rocks, their style of alteration and the age of mineralization at the Deep River gold prospect, Randolph and Moore counties, North Carolina [abs]: Geological Society of America, v. 42, no. 1, p. 168 (Paper No. 72-1)

Saunders, J.A., 1990, Colloidal transport of gold and silica in epithermal precious metal systemsEvidence from the Sleeper deposit, Humboldt County, Nevada: Geology, v. 18, p. 757-760.

Seal, R.R., II, Ayuso, R.A., Foley, N.K., Clark, S.H.B., 2001, Sulfur and lead isotope geochemistry of hypogene mineralization at the Barite Hill gold deposit, Carolina slate belt, southeastern United

States-A window into and through regional metamorphism: Mineralium Deposita, v. 36, p. 137-148.

Shervais, J.W., Shelley, S.A., and Secor, D.T., 1996, Geochemistry of volcanic rocks of the Carolina and Augusta terrranes in central South Carolina-An exotic rifted volcanic arc?: Geological Society of America Special Paper 304, p. 219-236.

Sillitoe, R.H., and Hedenquist, J.W., 2003, Linkages between volcanotectonic settings, ore-fluid compositions, and epithermal precious metal deposits: Society of Economic Geologists Special Publication 10, p. 315-343.

Stein, H.J., Markey, B.J., Morgan, J.W., Zak, K., Zacharias, J., and Sundblad, K., 1996, Re-Os dating of Au deposits in shear zones using accessory molybdenite-Bohemian Massif, Carolina slate belt, and Fennoscandian shield examples: Geological Society of America Abstracts with Programs, v. 28, no. 7, p. A-474.

Tosdal, R.M., Dilles, J.H., and Cooke, D.R., 2009, From source to sinks in auriferous magmatichydrothermal porphyry and epithermal deposits: Elements, v. 5, p. 289-295.

Whitney, J.A., Paris, T.A., Carpenter, R.H., and Hartley, M.E., III, 1978, Volcanic evolution of the southern slate belt of Georgia and South Carolina-A primitive oceanic island arc: Journal of Geology, v. 86, p. 173-192.

Worthington, J.E., and Kiff, I.T., 1970, A suggested volcanogenic origin for certain gold deposits in the slate belt of the Carolina piedmont: Economic Geology, v. 65, p. 529-537.

Zwaschka, M., and Scheetz, J.W., 1995, Detailed mine geology of the Brewer gold mine, Jefferson County, South Carolina: Society of Economic Geologists Guidebook Series 24, p. 95-146.

\section{Additional References}

Ayuso, R.A., Seal, R.R., II, Foley, N.K., and Offield, T.W., 1998, Genesis of gold deposits in the Carolina Slate Belt, USA - Constraints from comparative mineralogy, trace elements, fluid evolution, and isotopic variations: Society of Mining Engineering, Abstracts with Program, Supplement to Mining Engineering, Annual Meeting, March 9-11, Orlando, Florida, p. 62.

Ayuso, R.A., Seal, R.R., II, Foley, N.K., Offield, T.W., and Kunk, M.J., 1997, Genesis of gold deposits in the Carolina Slate Belt, USA-Regional constraints from trace element, $\mathrm{Pb}$, and $\mathrm{Nd}$ isotopic variations and Ar-Ar ages [abs]: Geological Society of America, Abstracts with Program, v. 29, p. A-60.

Ayuso, R.A., Seal, R.R., II, Sinha, A.K., Foley, N.K., and Offield, T.W., 1999, Gold deposits of the Carolina Slate Belt-Zircon geochronology and isotopic characteristics: Geological Society of America, Abstracts with Program, v. 31, p. A-3. 
Foley, N.K., Ayuso, R.A., Seal, R.R., II, and Offield, T.W., 1997, Fluid evolution and mineralogy of Au-bearing volcanogenic deposits in a regional geologic setting-Examples from the Carolina Slate Belt, USA [abs]: Geological Society of America, Abstracts with Program, v. 29, p. A-59.

Foley, N.K., Ayuso, R.A., Seal, R.R., II, and Offield, T.W., 1998, Remnant colloform pyrite-A textural key to genesis of gold deposits in the Carolina slate belt [abs]: Geological Society of America, Abstracts with Program, v. 30, p. A-368.

Seal, R.R., II, Ayuso, R.A., Foley, N.K., and Clark, S.H.B., 1995, Geochemistry of supergene barite from the Barite Hill gold mine-Implications for acid mine drainage formation [abs]: Geological Society of America, Abstracts with Program, v. 27, p. A-117.

Seal, R.R., II, Clark, S.H.B., Ayuso, R.A., Foley, N.K., and Gray, K.J., 1994, Sulfur isotope geochemistry of hypogene mineralization at the Barite Hill gold deposit, S.C-A window into and through regional metamorphism [abs]: Geological Society of America, Abstracts with Program, v. 26, p. A-82.

Seal, R.R., II, Foley, N.K., Ayuso, R.A., and Offield, T.W., 1997, Genetic significance of regional sulfur isotope variations in gold deposits of the Carolina Slate Belt, South Carolina [abs]: Geological Society of America, Abstracts with Program, v. 29, p. A-60. 